\title{
Mapping Influenza-Induced Posttranslational Modifications on Histones from CD8+ T Cells
}

\author{
Svetlana Rezinciuc ${ }^{1}$, Zhixin Tian ${ }^{2}$, Si Wu ${ }^{2}$, Shawna Hengel ${ }^{2}$, Ljiljana Pasa-Tolic ${ }^{2}$ and \\ Heather S. Smallwood 1,3,*iD \\ 1 Department of Pediatrics, University of Tennessee Health Science Center, Memphis, TN 38163, USA; \\ srezinci@uthsc.edu \\ 2 Environmental Molecular Sciences Laboratory, Pacific Northwest National Laboratory, Richland, WA 99354, \\ USA; zhixintian@tongji.edu.cn (Z.T.); si.wu@ou.edu (S.W.); shengel@seagen.com (S.H.); \\ Ljiljana.PasaTolic@pnnl.gov (L.P.-T.) \\ 3 Children's Foundation Research Institute, Memphis, TN 38105, USA \\ * Correspondence: hsmallwo@uthsc.edu; Tel.: +1-(901)-448-3068
}

Academic Editor: Italo Tempera Received: 10 October 2020; Accepted: 2 December 2020; Published: 8 December 2020

\begin{abstract}
T}$ cell function is determined by transcriptional networks that are regulated by epigenetic programming via posttranslational modifications (PTMs) to histone proteins and DNA. Bottom-up mass spectrometry (MS) can identify histone PTMs, whereas intact protein analysis by MS can detect species missed by bottom-up approaches. We used a novel approach of online two-dimensional liquid chromatography-tandem MS with high-resolution reversed-phase liquid chromatography (RPLC), alternating electron transfer dissociation (ETD) and collision-induced dissociation (CID) on precursor ions to maximize fragmentation of uniquely modified species. The first online RPLC separation sorted histone families, then RPLC or weak cation exchange hydrophilic interaction liquid chromatography (WCX-HILIC) separated species heavily clad in PTMs. Tentative identifications were assigned by matching proteoform masses to predicted theoretical masses that were verified with tandem MS. We used this innovative approach for histone-intact protein PTM mapping (HiPTMap) to identify and quantify proteoforms purified from CD8 $\mathrm{T}$ cells after in vivo influenza infection. Activation significantly altered PTMs following influenza infection, histone maps changed as T cells migrated to the site of infection, and $\mathrm{T}$ cells responding to secondary infections had significantly more transcription enhancing modifications. Thus, HiPTMap identified and quantified proteoforms and determined changes in CD8 T cell histone PTMs over the course of infection.
\end{abstract}

Keywords: epigenetic; histone; posttranslational modifications; T cells; influenza; top-down; mass spectrometry

\section{Introduction}

Clearance of viral infection depends upon a well-orchestrated immune response and requires precise control of the immediate effector $\mathrm{T}$ cell response as well as the formation and maintenance of the memory $\mathrm{T}$ cell population. Activation of naïve $\mathrm{T}$ cells $(\mathrm{Tn})$ initiates an autonomous program of differentiation and the acquisition of effector functions, including pro-inflammatory cytokine and cytolytic effector molecule production [1-5]. Effector CD8 T cells (Teff) modulate their transcriptional programs as they adapt to activation stimuli and immune resolution, which influences their differentiation status and function. Thus, in response to dynamic environmental conditions, naïve cells alter their signaling cascades and pathways, leading to the induction of cytokine production and robust cytolytic activity. After the resolution of viral infection, Teff populations contract, and a small population of pathogen-specific long-lived memory cells remain. Memory CD8 T cells (Tm) are 
imprinted during the primary infection, and their robust recall response dictates the efficiency of the secondary immune response. Thus, virus-specific Tm are preprogrammed to respond rapidly to subsequent infections without further differentiation [5-11]. It has long been appreciated that Tn, Tm, and Teff have distinct phenotypes and functions. Yet, the origin of Tm remains unclear as there is evidence for both their development early in activation as well as from fully differentiated Teff. It is certain that epigenetics plays a role in both $\mathrm{Tm}$ and Teff generation. However, we are just beginning to understand the underlying epigenetic mechanisms that control the maintenance of these subsets and their unique responses to infection.

During $\mathrm{T}$ cell activation, in addition to mobilizing signal transduction cascades and transcription factors to drive the production of proteins necessary for effector functions, enzymes that control the epigenetic imprinting of CD8 T cells are upregulated [12]. These epigenetic imprints are posttranslational modifications (PTMs) to histones and DNA that form heritable changes without altering primary DNA sequences [3,13-18]. In the case of histones, this produces unique proteoforms which are the different molecular forms created by PTMs to the protein product of each of the canonical histone genes (H1, H2A, H2B, H3, and H4) [19]. As they differentiate, T cells change histone PTMs at gene loci associated with effector function [3,13-17]. Thus, combinations of histone PTMs at discreet genomic locations can indicate transcription levels and regulate cell-type-specific gene expression patterns $[20,21]$. The amino-terminal histone tails protruding from the nucleosome subunits are the main PTMs sites for acetylation, methylation, and phosphorylation that directly alter DNA accessibility or act indirectly via binding or chaperoning other proteins $[22,23]$. Acetylation of lysine residues on histones reduces their positive charge, weakening the electrostatic interaction with DNA. This "permissive" state allows transcription factors to access genes in this region. Conversely, when histone deacetylases remove these PTMs, the structure condenses, thereby restricting access to the region [24]. Thus, maintenance of PTMs by these enzymes play central roles in controlling T cell development [25-27], regulatory function maintenance [28], CD8 T cell proliferation [29], and effector functions, including the anti-viral response of antigen-specific CD8 T cells [30,31]. In contrast to the on/off effects of acetylation, the effects of histone methylation are context-dependent. For example, trimethylation of histone 3 or 4 at lysine 4 or 9 , respectively, is transcriptionally permissive, while the location and degree of methylation of lysines 27 and 9 on $\mathrm{H} 3$ within gene loci typically correlates with transcriptional repression [21,32-41]. This context dependency comes into play when both marks are present (bivalent), resulting in genes that are poised for expression pending the removal of the repressive modification. Bivalent marks on $\mathrm{H} 3$ are thought to contribute to rapid T cell differentiation [42-44]. Mapping gene expression patterns at loci associated with H3K4me3 and H3K27me3 from Tn, Teff, and Tm revealed the expression of $\mathrm{T}$ cell lineage-defining genes correlated with phenotypic and functional differences between virus-specific CD8 T cell subsets [3]. Following influenza infection, the transition from naïve to effector $\mathrm{T}$ cell was characterized by the loss of repressive H3K27me3 at specific bivalent loci and provided a mechanistic basis for the coordinate regulation of transcription during differentiation.

$\mathrm{H} 3$ trimethylations are the most widely studied histone PTMs. However, the histone octamer contains two $\mathrm{H} 2 \mathrm{~A}$ and $\mathrm{H} 2 \mathrm{~B}$ dimers as well as a tetramer of $\mathrm{H} 3$ and $\mathrm{H} 4$ proteins. Given the emerging role of epigenetics in CD8 T cell regulation, deciphering the histone code is of immediate importance. Analyzing intact histones by top-down mass spectrometry (MS) is a major advantage when tackling the histone code because combinatorial patterns of modifications on a single histone molecule can be identified [45]. Here, we used two-dimensional liquid chromatography-MS/MS (2D LC-MS/MS) for histone-intact protein PTMs mapping (HiPTMap) of H2A, H2B, H3, and H4 purified from CD8 T cells following influenza infection. This approach allowed us to assess the dynamics of the PTM landscape in naïve and activated T cells in the primary infection, map PTMs as effector T cells migrated to the site of infection, and compare Tm with Teff from the primary and secondary responses. We identified 225 unique PTMs on histone proteoforms from the spleen, bronchial lavage fluid (BAL) and lungs, found distinct PTM combinations based on $\mathrm{T}$ cell subsets and found a significant increase in enhancer PTMs in Teff from the secondary response. HiPTMap is particularly valuable for advancing our 
understanding of T cell biology by providing relative quantification of PTMs in different cell states with minimal histone protein. Furthermore, these results demonstrate this approach and technological advancements in MS are poised to increase the identification of novel modification locations and combinations that will generate a complete map of the histone code in distinct $\mathrm{T}$ cell populations. Histone PTMs identified in this study may also shed light on new regulatory mechanisms and allow for the detection of new loci relevant to $\mathrm{T}$ cell function and fate. The extent to which histone modifications direct $\mathrm{T}$ cell differentiation and fate remain unclear. Identifying the histone code for $\mathrm{T}$ cells at different locations and times following influenza infection may elucidate functional mechanisms in chromatin regulation in CD8 T cells and provide new insights into epigenetic maintenance of T cell phenotypes.

\section{Materials and Methods}

\subsection{Infections and T Cell Extraction}

Female C57BL/6 mice (The Jackson Laboratory, Bar Harbor, ME, USA) were infected for 9 days for primary and $\geq 30$ days for memory or secondary challenge. Mice were intranasally infected with influenza A virus strain $\mathrm{A} / \mathrm{X}-31(\mathrm{H} 3 \mathrm{~N} 2)(\mathrm{X} 31)$ at $\mathrm{EID}_{50}=10^{6}$. For the challenge, at least 30 days prior to X31 infection, mice received an intraperitoneal injection of A/Puerto Rico/8/1934 at EID $50=10^{8}$. Mice were sacrificed at specific times after X31 infection (9 days for Teff ${ }^{1}, 7$ days for Teff ${ }^{2}$, and 30 days for Tm). In each experiment, we used 8-10 mice for Teff ${ }^{1}, 20-40$ for Tm, and 5-6 mice for Teff ${ }^{2}$ per group. Spleens were collected, and CD8 cells separated $[5,10,46]$ using B220, MHCII, CD11b, and DX5 (NK) antibody cocktail (Miltenyi Biotec, Auburn, CA, USA). Fluorescence-activated cell sorting (FACS) was used to isolate CD8 T cells. Activated splenic T cells were selected based on CD8 ${ }^{\text {hi }}$ CD $44^{\text {hi }}$ $\mathrm{CD} 43^{\text {hi }} \mathrm{CD} 25^{\text {hi }}$, and naïve cells were selected based on $\mathrm{CD} 8^{\text {hi }} \mathrm{CD} 44^{\text {low }} \mathrm{CD} 43^{\text {low }} \mathrm{CD} 25^{\text {low }}$. T cells from BAL were selected based on $\mathrm{CD} 8^{+} \mathrm{CD} 44^{\text {hi }} \mathrm{CD} 43^{\text {hi }+} \mathrm{CD} 25^{+}$, Lung CD8 ${ }^{+} \mathrm{CD} 44^{\text {hi }} \mathrm{CD} 43^{\text {hi }} \mathrm{CD} 25^{\text {mid-hi }}$. The use of CD25 with CD43 was recently shown to allow isolation of influenza-specific CD8 from the BAL, lung and spleen [10]. The pellets were resuspended in ammonium bicarbonate with protease inhibitor cocktail (Roche, Indianapolis, IN, USA). Histones were purified using a histone purification kit (Active Motif, Carlsbad, CA, USA) for purifying core histones while preserving modification states. Columns were poured for each group and kept constant. We followed the manufacturer's protocol for gravity flow separation of H2A, H2B, H3 and H4 core histones. Protein was purified from each group, and $9 \mu \mathrm{g}$ protein per run was used for MS analysis. For relative comparisons (e.g., naïve vs. active or active spleen vs. BAL vs. lung), mice and samples were treated as above, except histones were pooled for relative quantification (10 mice). Based on these and other preliminary experiments (DNS), we estimate 2-5, 10-15, or 1-2 mice per group are required for the primary, memory, and secondary response groups, respectively, for adequate coverage of all core histones with this method.

\subsection{Mass Spectra Acquisition}

We previously developed an optimized MS workflow for HiPTMap and provided a detailed MS configuration and separation strategy [47]. Briefly, purified histones (7.5-10 $\mu \mathrm{g})$ were separated in the first dimension using a Jupiter C5 column ( $5 \mu \mathrm{m}$ particles, $300 \AA$ pore size, $600 \mathrm{~mm} \times 200 \mu \mathrm{m}$ i.d.) (Phenomenex, Torrance, CA, USA). Two Model 100 DM 10,000 psi syringe pumps (ISCO, Lincoln, NE, USA) were used to maintain constant pressure (4000 psi) during separation. A gradient was generated by adding mobile phase $B$ to a stirred mixer of mobile phase A ( $2.5 \mathrm{~mL}$ volume at $100 \%$ "A" at time zero). Mobile phase A was 20\% acetonitrile (CAN) aqueous solution with 5\% isopropyl alcohol (IPA) and $0.6 \%$ formic acid (FA). Mobile phase B was 45\% ACN, 45\% IPA, and 0.6\% FA. The appropriate split flow rate was controlled by the combination of a packed column together with $15 \mu \mathrm{m}$ i.d. capillary, with an approximate flow of $10 \mu \mathrm{L} / \mathrm{min}$. RPLC separation was directly coupled with the mass spectrometer for comparative analyses (details provided below). Alternatively, we used a SPECTRA100 UV detector (Thermo Separation Products, Waltham, MA, USA) to monitor protein 
elution online at $214 \mathrm{~nm}$, and fractions were collected using a Cheminert column selector system (VICI, Houston, TX, USA).

Each histone family fraction was further separated in the second dimension by weak cation exchange hydrophilic interaction liquid chromatography (WCX-HILIC) using a $50 \mathrm{~cm} \times 100 \mu \mathrm{m}$ i.d. column prepared with PolyCAT A ( $5 \mu \mathrm{m}$ particles, $1000 \AA$ A pore size) (PloyLC, Columbia, MD, USA). We used a $70 \%$ ACN aqueous solution with $1.0 \%$ FA for mobile phase $\mathrm{A}\left(2^{\circ} \mathrm{A}\right)$ and $70 \% \mathrm{ACN}$ and $8 \%$ FA for mobile phase $\mathrm{B}\left(2^{\circ} \mathrm{B}\right)$ for the gradient in the second-dimension separation. To increase the throughput of the second dimension, we employed a ten-port nanovolume injection valve (VICI) to house two capillary columns, enabling separation and concurrent loading/equilibration between the two columns. Each isolated core histone fraction was loaded onto a $150 \mu \mathrm{m}$ i.d. $\times 5 \mathrm{~cm}$ solid-phase extraction column with HILIC stationary phase described above. After loading each fraction in mobile phase $2^{\circ} \mathrm{A}$, mobile phase $2^{\circ} \mathrm{B}$ was added to the mixing vessel to separate the proteoforms of each core histone for more effective MS characterization. We acquired spectra using electrospray ionization (ESI) high-resolution MS and MS/MS acquisitions in an LTQ Orbitrap Velos (Thermo Fisher Scientific, Waltham, MA, USA). ESI voltage was applied by connecting the end of the LC column to a capillary emitter with a polyether ether ketone (PEEK) union while voltage was applied [47]. Acquisitions with the Orbitrap had nominal resolving power of $60,000(\mathrm{~m} / \mathrm{z}=400)$. FTMS MS and MSn gain control were set at 1E6 and 3E5, respectively, with three micro scans each. Precursor ion fragments were isolated with a $1.5 \mathrm{~m} / \mathrm{z}$ window. The collision-induced dissociation (CID; normalized collision energy 35\%, $30 \mathrm{~ms}$ ) and electron transfer dissociation (ETD; reaction time $25 \mathrm{~ms}$ ) for the same precursor ion were alternated, and exclusion duration of $900 \mathrm{~s}$ and an exclusion list size of 150 were applied. MS/MS was only performed on species with charge states greater than four.

\subsection{Data Analysis}

Proteoforms, as well as PTMs, were identified by searching raw data against a mouse-specific annotated database, mouse op down database (1260319 basic sequences, 5,097,711 protein forms), using ProSightPC 2.0 software (Thermo Scientific) using the Xtract algorithm and top-down (MS2) default settings. The analysis was performed in single-protein search mode with dynamic modifications used for the identification of PTMs, including acetylation, mono-, di-, and trimethylation and phosphorylation with a mass tolerance of $10 \mathrm{ppm}$ for precursor and $10 \mathrm{ppm}$ for fragments using $\Delta \mathrm{m}$ mode (this function allows identification of proteoforms with PTMs not included in the annotated proteoform database). The minimum signal-to-noise $(\mathrm{S} / \mathrm{N})$, minimum reliability (RL), maximum charge and maximum mass were set to $1.0,0.9,40$, and $25 \mathrm{kDa}$, respectively. Individual spectra were searched in absolute mass mode if a minimum of six fragments and a minimum intact mass of 5000 Da were observed, and the fragment mass tolerance was set at $10 \mathrm{ppm}$. Due to limitations in the ProSightPC search tool (i.e., restricted to previously annotated PTMs), a manual analysis was performed in the few cases ProSightPC could not identify species of import between biological comparisons. Histone identifications were filtered by requiring the "number of best hits" to be one (globally unique ID). The false discovery rate (FDR) was evaluated using a reversed database search with the same filtering criteria, where FDR $=100^{*}$ Nreverse/Nforward. A P score cutoff of 0.00025 was chosen with FDR $<1 \%$. MS Access was used as a platform to align and normalize individual histones from a 2D display for further inference of LC-MS datasets of histone proteoforms generated from T cell subsets. Proteoforms obtained from the search were grouped in MS Access to give the final globally unique isoforms with normalized intensities across all the identified isoforms for quantitation. Histone PTM analysis is a computationally challenging process we refer readers to for details and tips to analyzing these data [47-51]. 


\section{Results}

\subsection{Nä̈ve Versus Activated T Cell Histone Modifications}

We previously used 2D LC-MS/MS) for HiPTMap of proteins purified from HeLa cells and demonstrated the high sensitivity and comprehensive characterization of histone PTMs [47]. Here, using our established methods [3,5,52], female C57BL/6 mice were intranasally infected with influenza strain X31, spleens harvested nine days later, and T cells isolated by FACS (Figure 1a). Histones were purified from $\mathrm{T}$ cell lysates and subjected to LC-MSanalysis. We used high-resolution reversed-phase liquid chromatography with tandem mass spectrometry (RPLC-MS/MS) on an Orbitrap Velos with alternating CID and ETD. We applied this MS method for HiPTMap of modifications that formed in vivo following intranasal infection with influenza virus. Both MS and MS/MS datasets were acquired with high-resolution and mass accuracy (intact protein below $1 \mathrm{Da}$ and fragment ions below $10 \mathrm{ppm})$. All core histones were loaded onto the columnand separated into individual families $\mathrm{H} 4$, $\mathrm{H} 2 \mathrm{~B}, \mathrm{H} 2 \mathrm{~A}$, and $\mathrm{H} 3$ that eluted in increasing order of molecular weight, which roughly correlates with increasing hydrophobicity (i.e., 11,352.5, 13,757.1, 14,019.9, and 15,350.8 Da, respectively) (Figure 1a-c). Proteoforms within each histone core family eluted together, except for H3. With reversed-phase separation, elution time is primarilyinfluenced by hydrophobicity. Thus, H3 eluted in two distinct peaks; the second peak contained H3 species with up to three additional methylations that increase their hydrophobicity (Figure $1 \mathrm{a}-\mathrm{c}$ ). This clear separation of histone core family members allows for facile separation, fragmentation, and downstream HiPTMap.

The high degree of similarity between various histone proteoform masses and the considerable difference in the amounts of each core histone (Figure 1b,c)necessitated a combination of high-resolution protein separation and high-performance MS analysis for the identification of individual histone proteoforms. Raw data were searched against mouse-specific annotated data to map top-down fragmentation spectral data to associated sequences for the identification of PTMs, including acetylation, mono-, di-, and trimethylation and phosphorylation. Supplemental File S1 lists the identified proteoforms, exact masses, and significance for identifications from the naïve and activated $\mathrm{T}$ cells (tabs A and B, respectively). We identified 166 unique histone proteoforms from naïve and activated CD8 T cells isolated from the spleens of mice infected with influenza for 9 days (Table 1). We validated the identity of these proteoforms using online nanoflow WCX-HILIC LC-MS/MS (data not shown). WCX-HILIC MS/MS uses specialized separation for the characterization of complex mixtures of hypermodified combinatorial proteins. However, WCX-HILIC only marginally increased the number of identified proteoforms in the naïve T cells, likely due to limited amount of material available for analysis. To reduce sample requirements, we continued with the RPLC-MS/MS-CID/ETD approach for HiPTMap and comparative analyses. 
Intranasal Infection X31

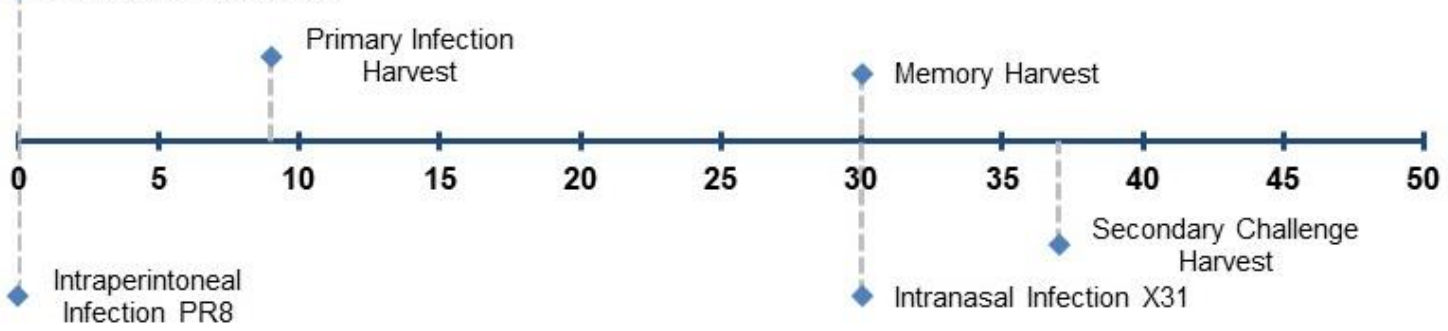

(a)

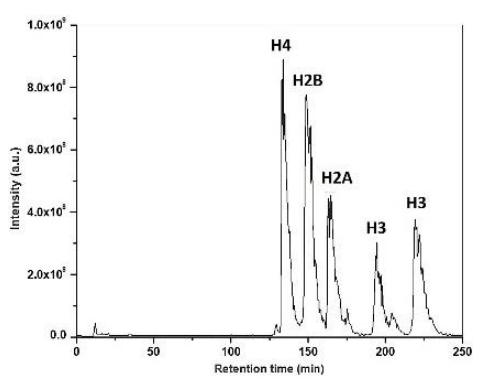

(b)

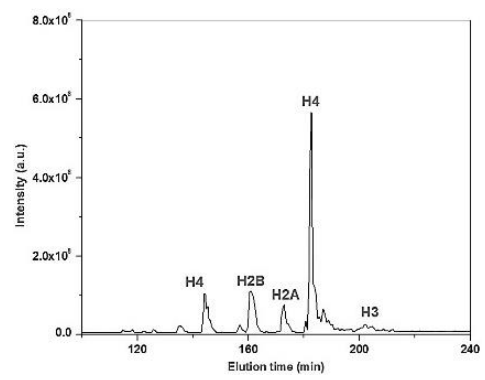

(c)

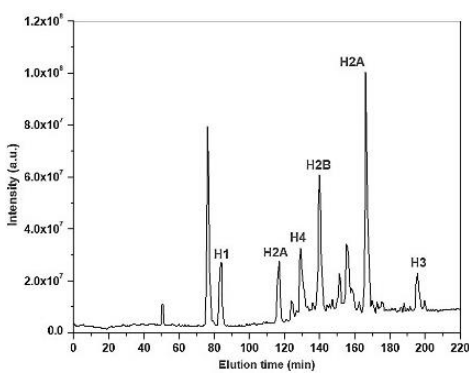

(d)

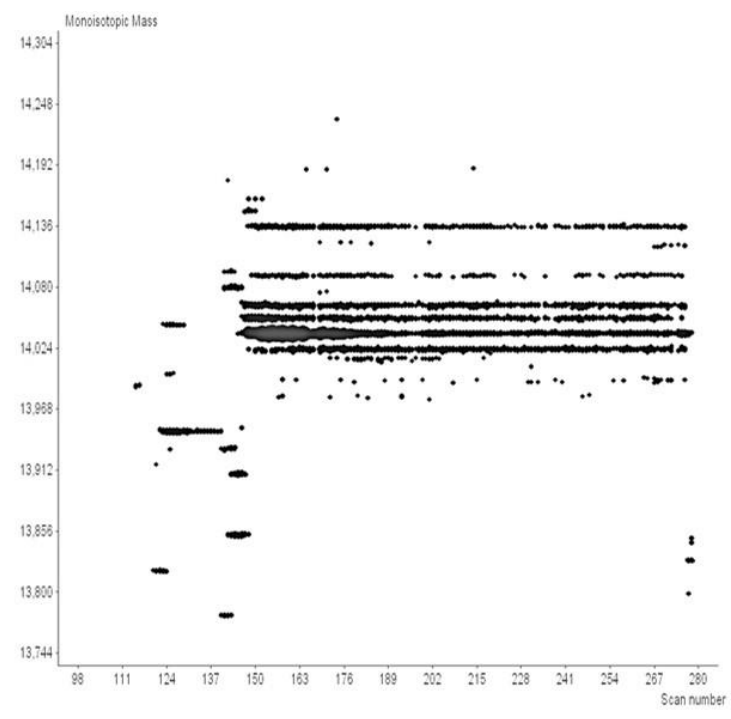

(e)

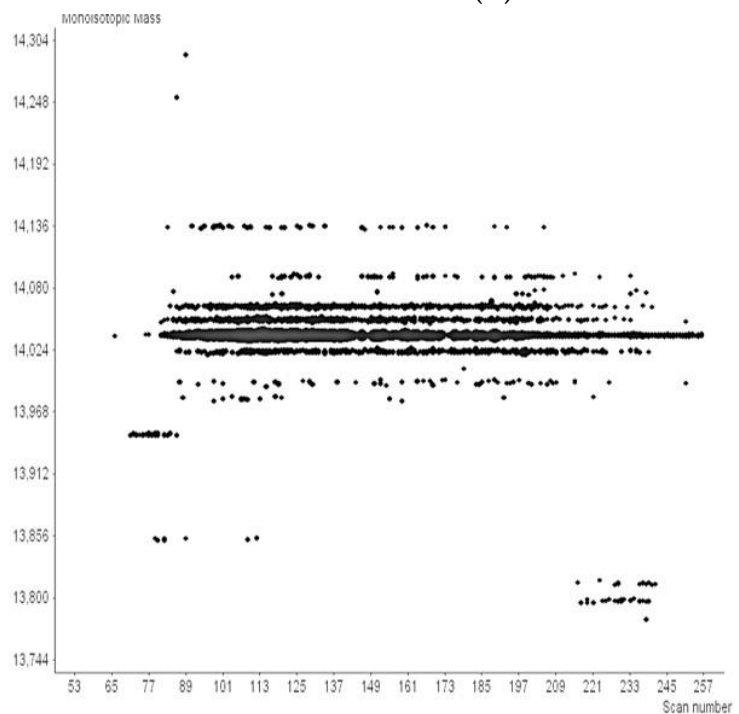

(f)

Figure 1. Representative mass spectral data of core histones from CD8 T cells. (a) Female C57BL/6 mice were used with 2-5, 10-15, or 1-2 mice per primary, memory, and secondary infection, respectively. Mice were intranasally infected with influenza A virus strain A/X-31(H3N2) (X31) at EID D0 $_{50}$ of $10^{6}$ and sacrificed on day 9 for the primary response or after 30 days for the memory response. For the secondary response, mice received intraperitoneal injections of PR8 at $\operatorname{EID}_{50}$ of $10^{8}$ and, after 30 days, were challenged with X31 as described above. These mice were sacrificed 7 days after the heterologous challenge. In the primary infection, bronchial lavage fluid (BAL) was taken from mice, lungs were profused then harvested, and spleens were harvested. Prior to sorting, crude cell preparations from mice were grouped, and contaminated immune cells were reduced by negative depletion. Enriched CD8 T cells were stained for surface markers and sorted by FACS. Naïve cells were selected based on CD8hi CD44low CD43low CD25low from the spleen in the primary. Activated T cells from the spleen were selected based on CD8hi CD44hi CD43hi CD25hi from the primary and secondary responses. Enriched Tm from the spleen were selected based on CD8hi CD44+ CD43+. T cells from BAL were selected based on CD8+ CD44hi CD43hi+ CD25+ and CD8+ CD44hi CD43hi CD25mid-hi from the lung. Histones were purified from $T$ cell populations using a histone purification kit (Active Motif, Carlsbad, CA, USA) for purifying core histones while preserving modification states. Each population 
had a dedicated column, and we followed the manufacturer's protocol for gravity flow separation of $\mathrm{H} 2 \mathrm{~A}, \mathrm{H} 2 \mathrm{~B}, \mathrm{H} 3$ and $\mathrm{H} 4$ core histones. $9 \mu \mathrm{g}$ of histone protein was used from each experimental replicate for MS analysis. For relative comparisons (e.g., naïve vs. active or active spleen vs. BAL vs. lung), mice and samples were treated as above except histones were pooled for relative quantification (10 mice each); (b) Histones were purified and subjected to RPLC-MS/MS analysis on an Orbitrap Velos mass spectrometer. Mass spectra were acquired with high-resolution to ensure isotopic resolution for all detected protein species. Representative data are provided for the total ion chromatograms of histones from HeLa cell standards (b), naïve CD8+ T cells (c) and activated CD8 T cells (d); (e,f) Two-dimensional displays depicting resolved intact protein masses of $\mathrm{H} 2 \mathrm{~A}$ from two independent experiments; species were detected using reversed-phase separation for activated T cells.

Table 1. Number of unique modified sequences identified from naïve and activated CD8 T cells.

\begin{tabular}{cccccccc}
\hline \multirow{3}{*}{ Naive } & H1F & H2A & H2B & H3 & H4 & Total \\
& Identified & & 30 & 18 & 18 & 25 & 91 \\
& Fragments & & 832 & 443 & 291 & 598 & 2164 \\
\multirow{4}{*}{ Active } & Unique & & 9 & 6 & 16 & 19 & 50 \\
& Identified & 1 & 39 & 12 & 10 & 13 & 75 \\
& Fragments & 21 & 635 & 356 & 139 & 279 & 1430 \\
& Unique & 1 & 10 & 5 & 9 & 12 & 36 \\
\hline
\end{tabular}

The number of proteoforms identified, the sum of their corresponding fragments ions detected, and the total number of unique modification combinations.

Histones from naïve $\mathrm{T}$ cells had more total unique modified species detected and identified than those from activated $\mathrm{T}$ cells (Table 1). H2A was the only core histone with more unique modified sequences from activated $\mathrm{T}$ cells, and six out of nine contained K5ac. This enhancer mark was predominantly associated with the activated T cells (Table S1). K5ac was distributed more frequently among PTM combinations after activation and with increased frequency. This trend remained true when K5ac was accompanied by serine 1 acetylation and/or threonine 120 phosphorylation (i.e., five found in activated T cells, one in naïve) (Table S1). R3Me2 and R4me2 were reduced or not detected after activation, but their function is currently unclear. Core histones from H2B, H3, and H4 had more unique modified species detected in histones purified from naïve T cells (Table 1). Lysine 108 acetylation was specific to H2B from naïve T cells (Table S1). The peak intensity of H3 was lower than that of other core histones (Figure 2), resulting in low overall intensities for $\mathrm{H} 3$ proteoforms from both naïve and activated $\mathrm{T}$ cells. However, $\mathrm{H} 3$ and $\mathrm{H} 4$ were generally more heavily modified, and these modifications were often associated with each other (Figure 2c,d and Table S1). For example, lysine 9 through 36 on $\mathrm{H} 3$ were often acetylated and/or methylated in groups as were those on $\mathrm{H} 4$, whereas serine 1 acetylation was often accompanied by acetylation at positions 12 and 16 and methylation at position 20 (Figure $2 \mathrm{~d}$ and Table S1). In general, H4 had a relatively high level of triple and quadruple modifications that were distributed on a few amino acids (Figure $2 \mathrm{~d}$ and Table S1) and was high in abundance for both $\mathrm{T}$ cell subsets (Table S2). One modification on $\mathrm{H} 4$ that was detected on twice as many unique sequences in the naïve subset was serine 1 acetylation (Table S1), and these proteoforms had higher relative intensities when compared to activated T cells (Table S2). In fact, several of the H4 S1ac proteoforms were not detected in activated T cells (e.g., S1acK12acK16ac, S1acK12acK16acK20me3, S1acK16ac, S1acK16acK20me, S1acR3me2K20me3, and S1acR3meK20me2). S1ac and R3me appear to be mutually exclusive, and the latter was more evenly distributed across the T cell states (Figure 2d). This is similar to H3, where arginine methylation restricts phosphorylation of S1. Given that the proteoforms containing S1ac account for 38\% of total histone proteoforms in the naïve $\mathrm{T}$ cells and only $13 \%$ in activated $\mathrm{T}$ cells, this mark may be of importance prior to activation (Table S2). These findings indicate individual and combinations of PTMs are distinct in naïve versus activated $\mathrm{T}$ cells from primary influenza infection. 


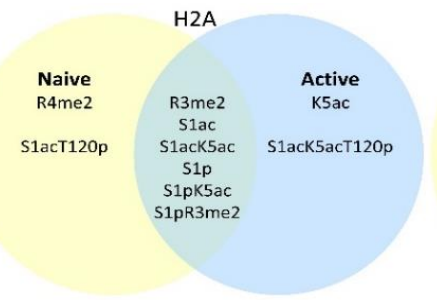

(a)

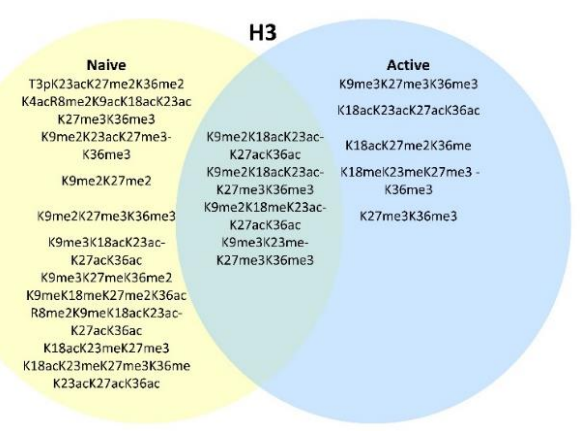

(c)

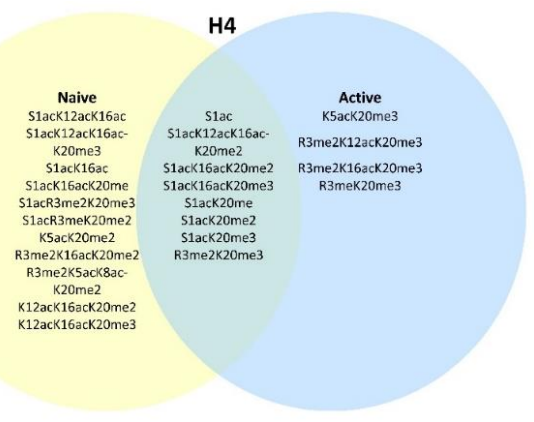

(d)

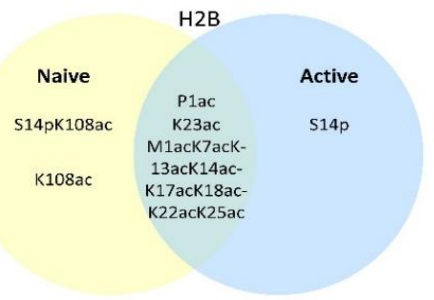

(b)

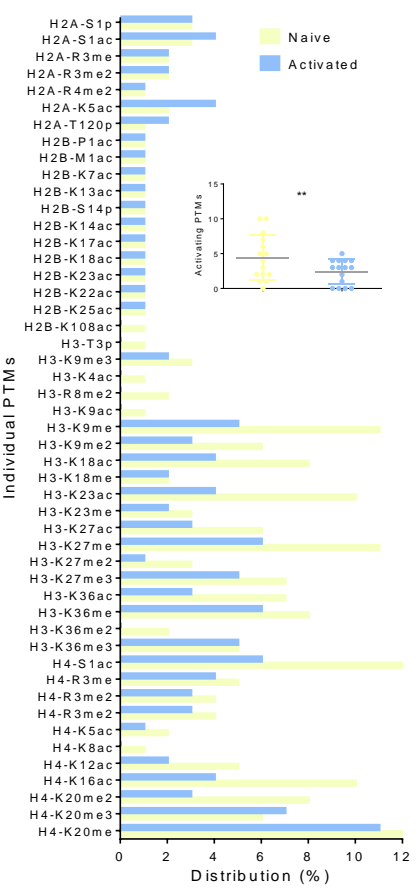

(e)

Figure 2. Histone-intact protein PTM mapping (HiPTMap) of naïve and activated CD8 T cells. (a-d) Histones purified from naïve $\left(\mathrm{CD} 8^{\text {hi }} \mathrm{CD} 44^{\text {low }} \mathrm{CD} 43^{\text {low }} \mathrm{CD} 25^{\text {low }}\right)$ or activated $\mathrm{T}$ cells $\left(\mathrm{CD} 8^{\text {hi }}\right.$ $\mathrm{CD} 44^{\text {hi }} \mathrm{CD} 43^{\text {hi }} \mathrm{CD} 25^{\mathrm{hi}}$ ) purified by FACS of splenocytes from mice 9 days after intranasal infection with influenza and subjected to RPLC-MS/MS using Orbitrap Velos with alternative collision-induced dissociation (CID)/alternating electron transfer dissociation (ETD). Raw datasets were searched against the mouse top-down database. PTMs including acetylation, mono-, di-, and tri-methylation and phosphorylation were detected; (e) the individual modifications from each proteoform were combined to yield the sum of each PTM per core histone. A Wilcoxon matched-pairs signed-rank test was performed (** $p<0.0001)$ with pairing evaluated by Spearman correlation $\left({ }^{* *} p<0.0001\right)$. Inset: the number of enhancer PTMs (H4-K8ac, H3-K36me2, H3-K9ac, H2B-K12ac, H4-K5ac, H3-K36me3, H4-K12ac, H4-R3me2, H3-K36ac, H3-K27ac, H2A-S1p, H4-K16ac, H3-K23ac, H3-K18ac, and H2A-K5ac) were compared for the activated and naïve with paired $t$-test $(p=0.0046)$. 
To better compare histone proteoforms from naïve and activated $\mathrm{T}$ cells, we normalized one representative dataset with the total histone proteoform intensities within the naïve and activated $\mathrm{T}$ cells (Table S2). H2A accounted for the largest percentage of histone cores in activated $\mathrm{T}$ cells. We found acetylation of serine 1 on $\mathrm{H} 2 \mathrm{~A}$ (S1ac) was increased in relative intensity (i.e., $23.4 \%$ versus $6.5 \%$ ) and in the number of unique sequences identified in activated versus naïve T cells (Tables S1 and S2). The relative abundance of proteoforms with phosphorylated serine 1 was also higher in activated versus naïve T cells (i.e., $21.3 \%$ versus $7.0 \%$ ) (Table S2). Overall, H2B showed very few differences in counts or relative abundance for naïve and activated T cell subsets (Tables S1 and S2). However, both the fragment numbers and peak intensity of P1ac were higher for H2B from activated T cells (Figure 2b and Table S1). Interestingly, we identified four times more H2BS14p fragment ions from activated T cells than from naïve (i.e., 24 to 6). The relative abundance of $\mathrm{H} 3$ was the same irrespective of activation (Table S2). H4 was the dominant species in the naïve T cells. Acetylation of serine 1 accounted for $38.1 \%$ of the proteoforms detected in naïve and only $13.6 \%$ in activated T cells. Indeed, when we compared acetylation of the first twenty amino acids on $\mathrm{H} 4$, it encompassed $50.7 \%$ of all species from naïve $\mathrm{T}$ cells versus $20.5 \%$ from activated $\mathrm{T}$ cells. Apart from these exceptions, the majority of modified species we identified were present in histones from naïve and activated $\mathrm{T}$ cells to a similar extent (Tables S1 and S2).

To determine if individual modifications changed following activation, compared the total number of times each PTM was identified on the proteoforms of each core histone family member (Figure 2e). The distribution and median of PTMs per core histones from naïve and activated T cells were significantly different (Figure 2e). Six modifications were detected in naïve but not in activated T cells: H2BK108ac H3T3p, H3K4ac, H3R8me2, H3K9ac, and H4K8ac (Figure 2b,c and Table S1). Of these, H3K9ac and H4K8ac are associated with active gene expression, while H3R8me2 is associated with repression [53-56]. H3 lysine 27 was also acetylated; this activation signal was detected twice as many times for naïve T cells than for activated (i.e., 108 versus 51 fragments corresponding to 6 versus 3 unique proteoforms). Overall, we detected significantly more known enhancers of gene expression for naïve $\mathrm{T}$ cells (Figure 2e inset). There was not a significant difference in total repressive marks between naïve and activated T cells (DNS). However, we found a reduction in H3K27me2 and H3K27me3 repressive marks in activated T cells (i.e., 102 versus 68 fragments) (Figure 2e). This was consistent with previous findings [3], and this trend also occurred for dimethylations and monomethylation of lysine 27 (Table S1 and File S1A,B). Given H3K27me3 is associated with repression of transcription of genes in loci related to effector function, these data are consistent with the decommissioning of these repressive marks following $\mathrm{T}$ cell activation.

\subsection{Differences in Effector T Cell Histone Modification from the Spleen, Lung, and Bronchial Lavage}

Influenza infection activates CD8 T cells to expand and differentiate into Teff that migrate to the respiratory tract and contribute to viral clearance [4]. We sought to determine if the relative abundance of histone modifications changed as Teff migrated to the site of infection. We compared Teff from the spleen, lung, and BAL removed from the same mice nine days following influenza infection. Identical proteoforms were grouped, and intensities normalized across species for relative quantification. The observed masses, number of fragments per proteoform, PTMs per proteoform, associated $p$ values and normalized intensities values are provided in Supplemental File S2. We found acetylation of alanine one on H1F was similar in Teff from the lung and spleen (Figure 3A). In contrast, we found ten modified forms of H2A (Figure 3B). Acetylated serine one (S1ac) had the most modified product fragments ions detected in the MS2 and the highest relative intensity. Interestingly, S1ac appeared to trend lower in both number and intensity as Teff migrated to the infection site (Figure 3B). The same held true for H2A S1 phosphorylation (H2AS1p), which was previously associated with repression in embryonic development $[57,58]$ and chromatin relaxation to enhance transcription ribosome biogenesis and control of cell growth [59,60]. H2AS1p was accompanied by nearby R3me2 and K5ac, which were higher in the spleen than in the lung, and not detected in BAL (Figure 3B). It is notable that R3me2 
occurred in combination with H2A S1p, not S1ac, as acetylation at neighboring lysine residues is known to block methylation of arginine eight on H3. It is also remarkable that proteoforms with single R3me2 modifications were highly abundant in BAL, given proteoforms with R3me2 and S1p were only detected in Teff from the spleen. H2AK5ac was highly abundantin the lung, both as a single modification and accompanying S1ac (Figure 3B). This combination is intriguing because S1ac blocks phosphorylation at this site, which is a repressive mark, and K5ac is associated with transcriptional activation [61-64]. These acetylation events were accompanied by T120p, which is associated with increased gene expression and genomic stability in replicating cells $[65,66]$. By contrast, $\mathrm{H} 2 \mathrm{~B}$ had fewer PTMs, and the majority of species detected were unmodified, irrespective of Teff location (Figure 3C). H2B phosphorylation at serine 14 (S14p) is considered an epigenetic marker of apoptotic cells that works in opposition to the adjacent K15ac present in non-dying cells [67]. We detected some S14p in the spleen and lung (Figure 3E). Lysine 23 acetylation was the only modification we detected on H2B in Teff from BAL, while lysine 108 acetylation was detected only in Teff from the lungs. Lysine 108 acetylation has been widely reported in other tissues and systems, but its function remains unknown [68-71].

In contrast, H3 was heavily modified, many were bivalent, and these proteoforms were most abundant in Teff from the spleen and BAL (Figure 3D). Of all the core histones, H3 exhibited a stark pattern of PTMs changes based on Teff location (Figure 3D). Again, due to the higher complexity of $\mathrm{H} 3$, the normalized intensity of these proteoforms was relatively low. However, we identified many proteoforms that corresponded to numerous fragment ions. We did not detect H3K4me3, but this site was monomethylated and was detected only in Teff from the BAL (Figure 3D). Active gene loci are characterized by a combination of all three methylated forms of H3K4 and H3K4me, and H3K4me2 are found at both transcriptionally active promoters and distal regulatory elements and are considered activating signals [72-75]. Both H3K4me3 and H3K27me3 play an essential role in the polarization and activation of immune cells, including CD8 T cells [76-81]. We found repressive K27me3 on nine different H3 proteoforms combined with many other PTMs (Figure 3D). In addition, repressive $\mathrm{K} 9 \mathrm{me} 3$ was present in 12 out of the 23 proteoforms we confidently identified. Interestingly, we identified several $\mathrm{H} 3$ proteoforms with $\mathrm{K} 9$ methylations and $\mathrm{K} 27$ di- and trimethylations that were exclusively identified in Teff from BAL, especially when PTMs were absent in the intervening region (Figure 3D). This combination is also known for controlling the lineage commitment of both CD4 and CD8 T cells [82,83]. H3K18ac is associated with increased transcription in T cell activation [81,84]. H3K18ac was almost exclusively detected in Teff from the spleen with hyper-acetylation of neighboring lysines (Figure 4). Thus, while H3 wass of lower abundance, we found several modifications alone or in combination that are associated with $\mathrm{T}$ cell activation and lineage commitment. Given this included a large number of PTMs surrounding the well-studied H3K4me3 and H3K27me3 regulatory marks and the apparent enrichment of these species in different locations, exploring how these combinatorial patterns impact gene expression may be worthwhile. 


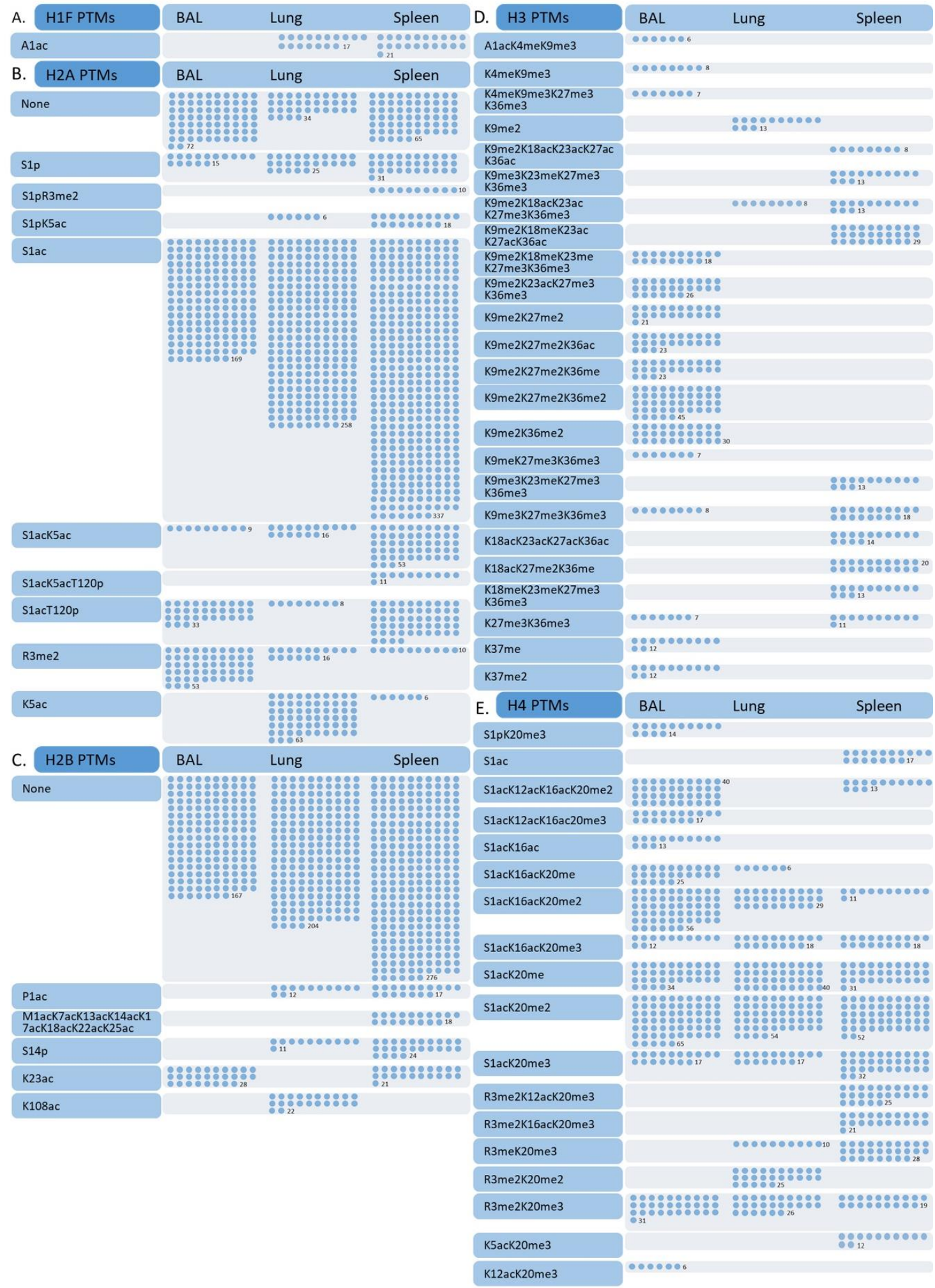

Figure 3. Distribution of modified species identified in histones purified from activated CD8 T cells isolated from BAL, lung, and spleen after influenza infection. Activated T cells were isolated from BAL, lung, and spleen 9 days after influenza infection using FACS (CD8 ${ }^{\text {hi }}$ CD $44^{\text {hi }}$ CD $43^{\text {hi }}$ CD25 ${ }^{\text {hi }}$ ). Histones were purified from each sample, subjected to activated T cells purified by FACS of splenocytes from mice 9 days after intranasal infection with influenza, and subjected to reversed-phase liquid chromatography (RPLC)-MS/MS-CID/ETD. Fragment ions identified per modified species $(\bullet)$ are indicated in score charts for H1F (A), H2A (B), H2B (C), H3 (D), and H4 (E). 


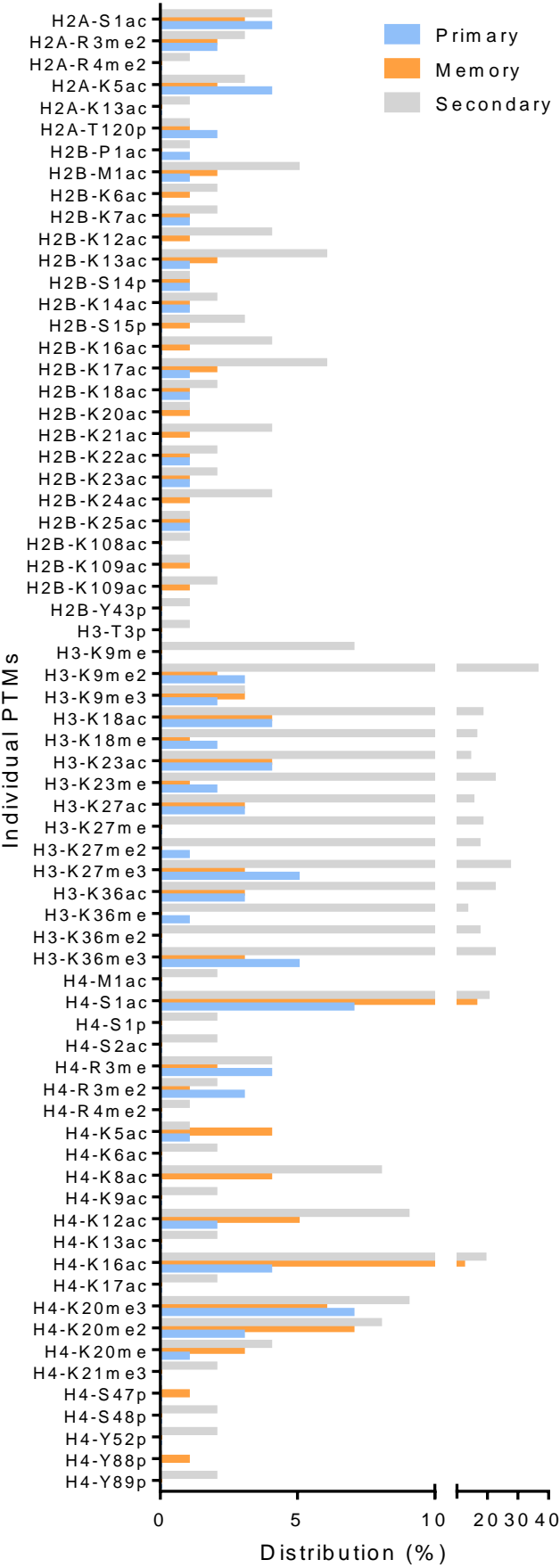

(a)
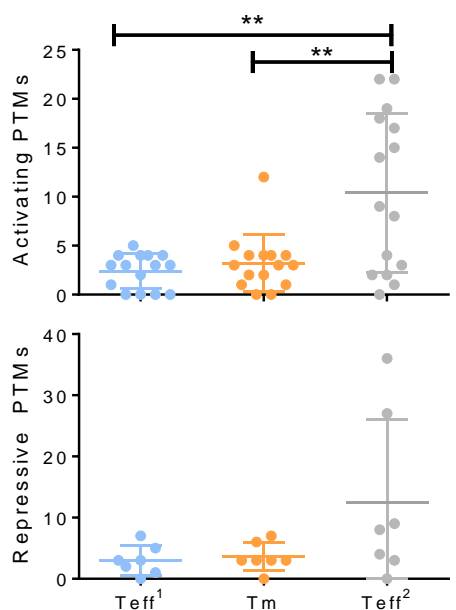

Figure 4. HiPTMapping of primary, memory, and secondary CD8 T cells. (a,b) Histones were purified from T cells and subjected to RPLC-MS/MS using Orbitrap Velos with alternative CID/ETD. Raw datasets were searched against the mouse top-down database. PTMs including acetylation; mono-, di-, and trimethylation; and phosphorylation were detected. The occurrence of each modification per proteoform was combined to yield the sum of each specific PTMs per core histone. (a) ANOVA (** $p<0.0001)$ was performed followed by Tukey's multiple comparisons test: $\operatorname{Teff}^{1}{ }^{1}, \mathrm{vs}$. Tm $(p=0.17)$, Tm vs. Teff ${ }^{2}(p<0.0001)$, and Teff vs. Teff ${ }^{2}(p<0.0001)$; (b) PTMs were separated into known activation marks (H2A-S1p, H2A-K5ac, H3-K36me2, H3-K9ac, H3-K27ac, H2B-K12ac, H3-K18ac, H3-K23ac, H3-K36ac, H3-K36me3, H4-K5ac, H4-K8ac, H4-K12ac, H4-K8ac, H4-R3me2, and H4-K16ac) and repressive marks (H3-R8me2, H3-K9me2, H3-K9me3, H3-K27me3, H4-K20me2, H4-K20me3, H4-K20me). Statistical comparison was with ANOVA $(p=0.007)$ followed by Tukey's multiple comparisons test $(p<0.005)$. 
Similar to $\mathrm{H} 3$, the tail region of $\mathrm{H} 4$ had multiple PTMs combinations, and most were bivalent (Figure 3E). The majority of these proteoforms were detected at a similar frequency and relative intensity in Teff from the BAL, lung, and spleen. The only exception was S1p, accompanied by K20me3, which was found exclusively in Teff from the BAL, was highly abundant (9\%) and had several matched fragments (Figure 3E). Like acetylation, phosphorylation of histone tails alters their charge and changes electrostatic interactions to relax chromatin. H4S1p has been implicated in the regulation of gene expression and control of cell phenotypes as well as decreasing histone acetyltransferase activity $[85,86]$. We also detected several H4 proteoforms with S1 acetylation. Both S1p and S1ac were associated with T cells from the BAL. We also identified several H4 proteoforms with R3me2; R3me2 is associate with the loss of S1p. Interestingly almost all H4 proteoforms had either S1 modification or R3me2, and these modifications were never present on the same proteoform (Figure 3E). This may indicate, in addition to phosphorylation, R3me2 can also block acetylation at serine one. However, R3me2 was detected in combination with several other modifications, including K12ac and K16ac and K20me2 and K20me3 (Figure 3E). These H4 lysine modifications alter binding affinity and may play a role in enhancing or inhibiting regional regulatory complexes [87]. We also identified two other modifications, $\mathrm{K} 5 \mathrm{ac}$ and K12ac, that are associated with transcriptional activation [61-63]. Taken together, these data indicate a previously unappreciated role for histone modification dynamics in Teff during migration to infection sites.

\subsection{Histone Modifications in Memory and Effector T Cells Following Influenza Infection}

There are fundamental differences in the response of naïve versus educated $\mathrm{T}$ cells to infection. In response to primary infection, $\mathrm{T}$ cell expansion peaks around day 9 or 10 days. This is followed by contraction, leaving 5-10\% of antigen-specific CD8 T cells to form the remaining pool of memory cells. In a subsequent secondary infection, these cells expand more robustly and mediate viral clearance faster. We compared the histones from Teff on day 9 of the primary response to X31 (Teff ${ }^{1}$ ) to early central Tm on day 30 and to activated T cells collected 7 days following a heterologous challenge $\left(\mathrm{Teff}^{2}\right)$. All mice were intranasally infected with influenza strain X31. However, for the secondary response, mice were primed with PR8 influenza strain at least 30 days prior to infection with X31 (Figure 1). We used the heterologous PR8/X31 prime challenge model because in mice, a homologous challenge results in sterilizing immunity without appreciable T cell expansion. The X31 and PR8 strains express different surface HA and NA proteins, so this prime challenge model avoids cross-reactive neutralizing antibodies. There is some naïve response to the heterologous HA and NA, but these Teff $^{1}$ lag behind Teff ${ }^{2}$ [88]. This is due to the conservation of the five dominant influenza epitopes in the internal genes of X31 and PR8. Thus, the Tm are already primed with PR8, and their expansion dominates the secondary response. Supplementary File S1 tabs B, C, and D contains the complete list of observed species, their masses, and $p$-values for Teff ${ }^{1}, \mathrm{Tm}$, and Teff ${ }^{2}$, respectively. We compared the occurrence of individual PTMs per condition (Figure 4). Histones from Teff ${ }^{2}$ had significantly more modifications than histones from Teff $^{1}$ or Tm (Figure $4 \mathrm{a}$ ). Interestingly, the transcriptional activation mark H2AK5ac [62,63] was similar for all subsets (Figure 4a and Table 2). Dimethylation of arginine 4 and acetylation of lysine 13 are known to target this area for biotinylation, which is involved in cell proliferation [89,90]. H2A R4me2 and K13ac were detected only in Teff ${ }^{2}$ (Figure 4a and Table 2). Apart from R4me2 and K13sc, PTMs on H2A appear in all three T cell subsets (Figure 4a). 
Table 2. H2A modifications from Teff ${ }^{1}$, Tm, and Teff ${ }^{2}$ after influenza infection.

\begin{tabular}{|c|c|c|c|c|c|c|}
\hline \multirow[t]{2}{*}{$\mathrm{H} 2 \mathrm{~A}$} & \multicolumn{2}{|c|}{ Teff $^{1}$} & \multicolumn{2}{|c|}{ Tm } & \multicolumn{2}{|c|}{ Teff $^{2}$} \\
\hline & Intact ID & Frag (\#) & Intact ID & Frag (\#) & Intact ID & Frag (\#) \\
\hline S1ac & 15 & 377 & 21 & 304 & 26 & 749 \\
\hline $\mathrm{S} 1 \mathrm{p}$ & 2 & 31 & 2 & 26 & 4 & 75 \\
\hline R3me2 & 1 & 10 & 1 & 1 & 3 & 13 \\
\hline R4me2 & & & & & 1 & 20 \\
\hline $\mathrm{K} 5 \mathrm{ac}$ & 6 & 6 & 6 & 6 & 5 & 5 \\
\hline S1acK5ac & 4 & 53 & 2 & 59 & 5 & 95 \\
\hline S1acR3me2K5ac & & & & & 2 & 21 \\
\hline S1acK5acT120p & 1 & 11 & & & & \\
\hline S1acT120p & 4 & 54 & 1 & 1 & 5 & 98 \\
\hline S1pK5ac & 2 & 18 & & & & \\
\hline S1pR3me2 & 1 & 10 & 1 & 9 & 3 & 74 \\
\hline K13ac & & & & & 1 & 12 \\
\hline None & 2 & 65 & 5 & 155 & 8 & 158 \\
\hline
\end{tabular}

Intact ID: the number of intact proteoforms identified containing listed modification(s). Frag \#: the number of fragment ions detected for the proteoforms.

When we compared modifications to H2B, we found Teff ${ }^{2}$ showed a high distribution of almost all proteoforms identified (Table 3 and Figure 4a). We identified P1ac on the H2B proteoforms in the Teff $^{1}$. When accompanied by a string of acetylations in this region, P1ac was detected in the Teff ${ }^{2}$ (Table 3). In contrast, acetylations at residues 16, 17, 18, 22, and 24 were detected in all three $\mathrm{T}$ cell subsets. Acetylations at lysine 7, 12, 13, and 14 were largely associated with Teff ${ }^{2}$, and Y42p on H2B were detected only in Teff ${ }^{2}$ (Figure 4a). Phosphorylation of serine 14 (S14p) on H2B is correlated with somatic hypermutation in vivo and class switch recombination [91]. We found H2BS14p was consistent across all three subsets (Figure 4a and Table 3). In contrast, K20ac was detected in Tm and Teff ${ }^{2}$ subsets (Table 3). This modification was previously detected on H2B [92] and was recently implicated as the site-specific homing and docking point for macroH2A1, which is required for the transcriptional activation of a myriad of cytokines, chemokines, metalloproteases [93]. Acetylation at lysine 108 or 109 in the tail region was also restricted to Tm and Teff ${ }^{2}$ (Figure $4 \mathrm{a}$ ).

Table 3. H2B modifications from Teff ${ }^{1}, \mathrm{~T}_{\mathrm{M}}$, and Teff ${ }^{2}$ after influenza infection.

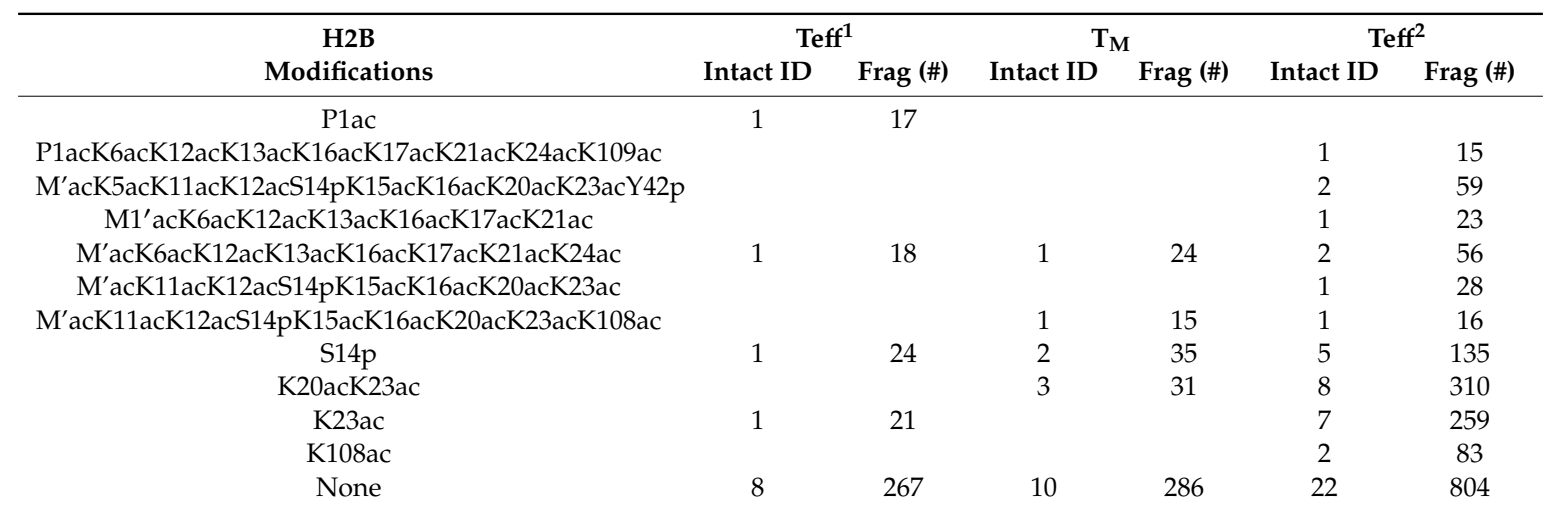

Intact ID: the number of intact proteoforms identified containing listed modification(s). Frag \#: the number of fragment ions detected from the proteoforms. $\mathrm{M}^{\prime} \mathrm{N}$-terminal initiator methionine.

We identified very few $\mathrm{H} 3$ proteoforms in Tm (Table 4 and File S1C). However, all H3 proteoforms identified in Tm were bivalent. We found methylation of lysine 9 and 27 on H3, and these repressive modifications were colocalized in three proteoforms from Teff ${ }^{1}$ versus twelve in Teff ${ }^{2}$. In general, these repressors were found in combination with activation marks. H3K27ac and H3K36ac are enhancer signals [94] that were also highly abundant in Teff ${ }^{2}$ (Figure 4a). However, lysine 36 can be methylated, which is a repressive signal [95]. H3K36 methylation was also highly abundant in Teff ${ }^{2}$ 
(Figure 4a). The most striking differences in individual PTMs on H3 were observed in regions 9 to 37, where these PTMs occurred in a variety of combinations (Figure 4a and Table 4). These unique proteoforms included several known enhancer and repressor signals (K4ac, K9me, K18ac, K23ac, K36ac, and K37me, [61,63,96-101] and R8me, K9me, and K27me [102-106], respectively). In some cases, $\mathrm{H} 3$ proteoforms differed by modifications with opposing functions on a single amino acid. For example, K9, as well as K36, can be acetylated or methylated to induce activation or repression of gene expression at nearby loci $[107,108]$. We also found evidence of bivalent "super-enhancers" with multiple activation signals on neighboring residues as well as a repressor signal in the flanking regions along with traditional bivalent marks. The abundance of $\mathrm{H} 3$ species with activation and repression marks indicates these histones may be poised to respond to external condition changes in these states. Indeed, all of the proteoforms from Tm were bivalent. In contrast, all of the H3 proteoforms with exclusively enhancer or repressor marks were detected in Teff, with a higher number in Teff ${ }^{2}$ (Table 4). Furthermore, the diversity and abundance of PTMs on H3 proteoforms in the secondary response support the notion that PTMs accumulate in terminally differentiated T cells.

$\mathrm{H} 4$ had fewer unique combinations of modifications than $\mathrm{H} 3$, but most $\mathrm{H} 4$ proteoforms were detected in Tm (Table 5). Serine 1 was acetylated in all T cell subsets but occurred in $80 \%$ of $\mathrm{H} 4$ proteoforms identified in Tm and in $43 \%$ and $32 \%$ of PTMs combinations from Teff ${ }^{1}$ and Teff ${ }^{2}$, respectively. S1 was also phosphorylated, but this modification was unique to Teff ${ }^{2}$ (Figure $4 \mathrm{a}$ and Table 5). This phosphorylation event is permissive and associated with proliferation [57]. S1p was accompanied by arginine 3 methylation (R3me), which is also an enhancer of gene expression $[99,109,110]$. R3me was present in both primary and secondary responses on multiple $\mathrm{H} 4$ proteoforms in combination with other activators and the repressive mark K20me [96,111-113]. $\mathrm{H} 4 \mathrm{~K} 5 \mathrm{ac}$ and K8ac are activation marks $[61-63,114,115]$ that were associated with Teff in both the primary and secondary responses (Table 5). Nearby, lysine 12 and 16 were also acetylated, and these are transcriptional activation signals $[61-63,114,116]$. H4 K12ac and K12ac were present in all subsets but were much lower in $\operatorname{Teff}^{1}$ (Figure 4a). Acetylation of lysine 9, another activation mark [53,54], was only detected in Teff ${ }^{2}$ (Figure 4a). Similar to $\mathrm{H} 2$, these activating acetylations were grouped closely together. Interestingly, K16ac was often accompanied by $\mathrm{K} 20$ di and trimethylation. These repressive marks were on approximately $50 \%$ of $\mathrm{H} 4$ proteoforms from Teff ${ }^{2}$ versus $75 \%$ and $88 \%$ of the H4 PTMs combinations from Teff ${ }^{1}$ and Tm subsets, respectively. Similar to H3, we found an abundance of H4 bivalent proteoforms that combined activating marks with the repressive K20me2 and K20me3. This was the only known repressor we identified on H4. However, it should be noted that mono-methylation of K20 can enhance or repress gene expression [96,111-113]. Thus, we found a myriad of histone proteoforms with unique combinations; some were shared among $\mathrm{T}$ cell subsets while others were unique or enriched in specific subsets. When we compared only the canonical enhancer and repressor PTMs, we found Teff ${ }^{2}$ had significantly more PTMs associated with activation than $\operatorname{Teff}^{1}$ or Tm (Figure $4 b$ ). 
Table 4. H3 modifications from Teff ${ }^{1}, \mathrm{~T}_{\mathrm{M}}$, and Teff ${ }^{2}$ after influenza infection.

\begin{tabular}{|c|c|c|c|c|c|c|}
\hline \multirow{2}{*}{$\begin{array}{c}\text { H3 } \\
\text { Modifications }\end{array}$} & \multicolumn{2}{|c|}{ Teff $^{1}$} & \multicolumn{2}{|c|}{$\mathbf{T}_{\mathbf{M}}$} & \multicolumn{2}{|c|}{ Teff $^{2}$} \\
\hline & Intact ID & Frag (\#) & Intact ID & Frag (\#) & Intact ID & Frag (\#) \\
\hline T3pK9me3K27me3K36me & & & & & 1 & 11 \\
\hline R8me2K9meK18acK23acK27acK36ac & & & 1 & 10 & & \\
\hline K9me2K18me & & & & & 1 & 29 \\
\hline K9meK18meK23meK27me & & & & & 1 & 32 \\
\hline K9meK18meK23meK27meK36me & & & 1 & 10 & 2 & 58 \\
\hline K9me2K18meK27me & & & & & 1 & 27 \\
\hline K9meK18meK27me2K36me & & & & & 4 & 124 \\
\hline$\overline{\mathrm{K} 9} \mathrm{me} 2 \mathrm{~K} 18 \mathrm{meK} 36 \mathrm{me} 3$ & & & & & 1 & 22 \\
\hline K9me2K18meK23acK27acK36ас & 2 & 29 & & & 1 & 28 \\
\hline K9meK18meK27meK36ac & & & & & 2 & 61 \\
\hline K9meK18acK23асK27асK36ас & 1 & 8 & 2 & 26 & & \\
\hline K9me'2K18acK23acK27me3K36me3 & 1 & 13 & 1 & 9 & 1 & 25 \\
\hline K9me2K18acK36ас & & & & & 1 & 24 \\
\hline K9me2K23meK27me & & & & & 2 & 58 \\
\hline K9meK23meK27meK36me & 1 & 13 & & & 4 & 98 \\
\hline 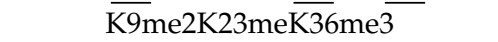 & & & & & 1 & 26 \\
\hline K9me2K23meK27meK36ac & & & & & 1 & 31 \\
\hline K9me2K23acK27acK36ac & & & & & 1 & 24 \\
\hline K9me2K23acK27me3K36me3 & & & & & 2 & 47 \\
\hline K9me3K23acK27acK36me3 & & & & & 1 & 24 \\
\hline K9me2K27me & & & & & 6 & 168 \\
\hline K9meK27meK36me & 1 & 18 & 1 & 7 & 17 & 501 \\
\hline$\overline{\mathrm{K} 9} \mathrm{me} 2 \overline{\mathrm{K} 2} 2 \mathrm{ac}-$ & & & & & 2 & 53 \\
\hline K9me2K27acK36me & & & & & 2 & 47 \\
\hline K9me2K27acK36ас & & & & & 1 & 29 \\
\hline K9me2K27me2K36ac & & & & & 3 & 76 \\
\hline $\mathrm{K} 9 \mathrm{me} 2 \mathrm{~K} 36 \mathrm{ac}$ & & & & & 3 & 77 \\
\hline K9me2K36me & & & & & 4 & 110 \\
\hline K18meK23meK27me3K36me3 & 1 & 13 & & & 1 & 26 \\
\hline K18acK23meK27me3K36me & & & & & 2 & 49 \\
\hline K18acK23acK27acK36ас & 1 & 14 & & & 1 & 23 \\
\hline K18acK23meK27acK36ac & & & & & 2 & 56 \\
\hline K18acK23acK27meK36ac & & & & & 1 & 26 \\
\hline K18acK23acK27meK36me & & & & & 4 & 109 \\
\hline K18acK23meK27me $2 K 3 \overline{6 a c}$ & & & & & 1 & 22 \\
\hline K18acK23meK27me3 & & & & & 1 & 32 \\
\hline K18meK27me3K36me3 & & & & & 1 & 16 \\
\hline K18acK27acK36ас & & & & & 2 & 52 \\
\hline K18acK27acK36me & & & & & 4 & 100 \\
\hline K18acK27meK36me & 1 & 20 & & & 2 & 61 \\
\hline K18acK27meK36ac & & & & & 2 & 48 \\
\hline K23meK27me3 & & & & & 3 & 72 \\
\hline K23meK27me3K36me & & & & & 7 & 185 \\
\hline K23meK27meK36ac & & & & & 2 & 60 \\
\hline K23acK $\overline{27 m e}$ & & & & & 1 & 31 \\
\hline K23acK27me3К36ас & & & & & 1 & 22 \\
\hline K23acK27meK36me & & & & & 4 & 107 \\
\hline $\mathrm{K} 27 \mathrm{acK} 36 \mathrm{ac}$ & & & & & 5 & 137 \\
\hline K27acK36me & & & & & 4 & 119 \\
\hline $\mathrm{K} 27 \mathrm{me} 2$ & & & & & 1 & 30 \\
\hline K27meK36me & 1 & 11 & & & 10 & 268 \\
\hline $\mathrm{K} 27 \overline{\mathrm{meK}} 3 \overline{6 \mathrm{ac}}$ & & & & & 3 & 89 \\
\hline
\end{tabular}

Intact ID: the number of intact proteoforms identified containing listed modification(s). Frag \#: the number of fragment ions detected for the proteoforms. Underline indicates methylations were combined. 
Table 5. H4 modifications from Teff ${ }^{1}, \mathrm{~T}_{\mathrm{M}}$, and Teff ${ }^{2}$ after influenza infection.

\begin{tabular}{|c|c|c|c|c|c|c|}
\hline \multirow{2}{*}{$\begin{array}{c}\mathrm{H} 4 \\
\text { Modifications }\end{array}$} & \multicolumn{2}{|c|}{ Teff $^{1}$} & \multicolumn{2}{|c|}{$\mathbf{T}_{\mathbf{M}}$} & \multicolumn{2}{|c|}{ Teff $^{2}$} \\
\hline & Intact ID & Frag (\#) & Intact ID & Frag (\#) & Intact ID & Frag (\#) \\
\hline S1ac & 1 & 17 & & & 1 & 15 \\
\hline S1pR3me & & & & & 1 & 6 \\
\hline S1pR3meK20me3 & & & & & 2 & 23 \\
\hline S1acR3meK20me2 & & & 1 & 14 & & \\
\hline S1acK5acK8acK12acK16ac & & & & & 2 & 22 \\
\hline S1acK5acK8acK12acK16ac & & & 1 & 19 & & \\
\hline S1acK5acK8acK12acK16acK20me2 & & & 1 & 13 & & \\
\hline S1acK5acK8acK16acK20me & & & 1 & 23 & & \\
\hline S1acK5acK12acK16acK20me & & & 1 & 27 & & \\
\hline S1acK8acK12acK16ac & & & & & 2 & 43 \\
\hline S1acK8acK12acK16acK20me & & & 1 & 56 & 3 & 48 \\
\hline S1acK8acK16acK20me & & & & & 5 & 135 \\
\hline S1acK12acK16ac & & & & & 3 & 69 \\
\hline S1acK12acK16acK20me & 1 & 13 & 2 & 78 & 7 & 202 \\
\hline S1acK16ac & & & 1 & 12 & 4 & 79 \\
\hline S1acK16acK20me & 2 & 29 & 5 & 191 & 10 & 301 \\
\hline S1acK16acK20me3S47p & & & 1 & 9 & & \\
\hline S1acK20me & 4 & 115 & 6 & 241 & 9 & 266 \\
\hline S1acK20me3Y88p & & & 1 & 19 & & \\
\hline R3me2K12acK20me3 & 1 & 25 & & & & \\
\hline R3me2K16acK20me & 1 & 21 & & & 1 & 10 \\
\hline R3meK20me & 2 & 47 & 1 & 23 & 2 & 25 \\
\hline $\mathrm{K} 5 \overline{\mathrm{acK}} 20 \mathrm{me} 3$ & 1 & 12 & & & & \\
\hline K16ac & & & 1 & 13 & & \\
\hline K16acK20me & & & & & 2 & 31 \\
\hline $\mathrm{K} 20 \mathrm{me}$ & & & 2 & 97 & 2 & 34 \\
\hline $\begin{array}{l}\text { M1acS2acK6acK9acK13acK17acK21me3- } \\
\text { S48pY52pY89p }\end{array}$ & & & & & 1 & 6 \\
\hline $\begin{array}{c}\text { M1acS2acR4me2K6acK9acK13acK17ac- } \\
\text { K21me3S48pY52pY89p }\end{array}$ & & & & & 1 & 6 \\
\hline None & & & & & 2 & 24 \\
\hline
\end{tabular}

Intact ID: the number of intact proteoforms identified containing listed modification(s). Frag \#: the number of fragment ions detected for the proteoforms. Underline indicates mono, di, and trimethylation were combined.

\section{Discussion}

Histone modifications in the respiratory tract have been associated with respiratory inflammation and infection, including SARS-CoV $[117,118]$. Influenza induces modifications that alter the expression of some pro-inflammatory cytokines and interleukin genes, but this is largely associated with DNA methylation during viral replication [119-126]. Thus, the epigenetic changes we observed in $\mathrm{T}$ cells are not likely to induce by the influenza virus itself. We found histone PTMs profiles differed in Teff isolated from the spleen, lung, and BAL following influenza infection (Figure 3). Others have demonstrated that location can impact epigenetic programming in innate immune cells and CD8 $T$ cells $[127,128]$. We posit this is due to their distinct microenvironments and may enhance functional differences in the $\mathrm{T}$ cell subsets at discreet locations. The interstitial $\mathrm{T}$ cells of the lung and airway $\mathrm{T}$ cells in the BAL are functionally different (e.g., more cytolytic versus more rapid cytokine response, respectively), and the quantity of BAL Teff correlates with protection during influenza infection. Recently, using the same PR8-X31 prime challenge model, Hayward et al. assessed the chromatin accessibility of influenza-specific T cells from the lung and BAL [128]. They found coordinated changes in chromatin accessibility and gene expression that suggested their epigenetic architecture was influenced by their environment and concluded amino acid starvation was the underlying mechanism. However, we interpret changes in amino acid starvation pathways to be downstream of the metabolic response to changes in substrate concentration in the microenvironment. Metabolism is sensitive to nutrient concentrations and exerts direct and indirect control of epigenetic 
programming [129-132]. T cell subsets have distinct metabolic phenotypes that may render them more sensitive to the availability of nutrients in their microenvironment, and this is likely to contribute to location specific epigenetic programming.

Previous studies profiled PTMs at certain effector gene loci and determined these marks were associated with genes that are critical to subset specific $\mathrm{T}$ cell functions, including human naive and memory CD8 T cells. These studies found associations between gene expression and the amounts of H3K4me3 (positive correlation) and H3K27me3 (negative correlation) across the gene body [81,133,134]. Araki and co-workers defined 4 associations between the ratios of H3K27me3 and H3K4me3 and gene expression: repressed, active, poised, and bivalent (i.e., high and low with low expression, low and high with high expression, low and high with low expression, and high and high with constant low expression in Tn that increases when Tm are activated) [81]. A similar approach demonstrated, after in vivo differentiation into influenza-specific Teff, H3K27me3 decreased, and H3K4me3 increased at immune-related effector gene promoters [3]. We used an unbiased approach and did not identify H3K4me3 or mine the data to identify or quantify this species. However, we found a reduction in H3K27me2 and H3K27me3 repressive marks that were associated with $\mathrm{T}$ cell activation (Figure $2 \mathrm{~b}$ and Table S1). We identified more unique combinations of PTMs from naïve than activated T cells isolated from the same samples, as well as significantly more individual PTMs and known markers of transcriptional activation (Figure $2 b$ inset). Moreover, after a secondary recall response to the heterologous influenza challenge, activation of Tm significantly increased the number of PTMs known to mediate transcriptional activation compared to naïve, Teff ${ }^{1}$, or Tm. This was largely due to several internal acetylations of lysine 9, 18, 23, 27 and 36 on H3 associated with transcriptional activation [135]. This was complemented by di- and trimethylation at lysine 36, a strong enhancer of transcriptional activation in T cells. Indeed, increased chromatin accessibility via hyperacetylation of this region is a potentially important mechanism for rapid re-expression of effector genes that facilitates the unique capacity for rapid recall of effector CD8 T cells [24]. Araki and Russ et al. established that H3K4me3 and H3K27me3 are reliably associated with genes that regulate $\mathrm{T}$ cell differentiation, and function via these marks positively and negatively correlating with the expression patterns of many critical genes and established methylation dynamics at bivalent regions regulate Tm by making these gene loci poised for rapid expression $[3,81]$. Our findings add to this knowledge by defining new PTMs combinations and deciphering the histone code by mapping these epigenetic hot spots in distinct CD8 T cell subsets over the course of in vivo influenza infection. We identified many new bivalent combinations in $\mathrm{T}$ cell subsets and found significant differences in the distribution of individual PTMs with activation and across $T$ cell subsets and significantly more enhancer PTMs in Teff ${ }^{2}$.

Based on the correlations of H3K4me3 and H3K27me3 with gene expression profiles in $\mathrm{T}$ cell subsets detailed above, many have integrated these epigenetic patterns into the two current models of T cell differentiation [136-138]. The circular T cell differentiation model suggests plasticity in T cells such that memory precursors, formed early after activation, gain effector function while maintaining the ability to form a pool of memory subsets. In this cycle, Tn differentiate into effector T cells, and a few develop into Tm that are activated in subsequent infections to repeat this process. It is postulated that the cycles of differentiation, dedifferentiation, and redifferentiation would result in oscillations in gene expression as well as epigenetic marks [136-138] (Figure 5a). In the linear differentiation model, naïve cells are fully activated into effector $T$ cells that contract while memory subsets form from naïve cells that are activated at the end of the infection and do not receive the necessary signaling to form Teff. Thus, it is postulated that the transcriptional and epigenetic programs of these transitional Tm will overlap with Tn and Teff and accumulated on or off signals resulting in a progressive increase or decrease in gene expression and related epigenetic marks [138] (Figure 5b). Presumably, these accumulated on or off signals would then be amplified in the secondary response. There is substantial evidence to support both differentiation models, and they remain a contested topic in T cell biology. To determine if individual histone PTMs fit these models, we used a qualitative approach. We determined the presence of each PTM and considered its accumulation based on the 
number of times that modification was identified alone or in unique PTM combinations for each T cell subset (i.e., unique proteoforms with the same PTMs combinations were combined, and we did not account for the number of times a proteoform was identified, the number of corresponding fragments, or their intensities). Using this high level on/off and up/down approach, we found evidence that some PTMs are constant while others oscillate in frequency or accumulate as T cells differentiate (Figure $5 c$ ).

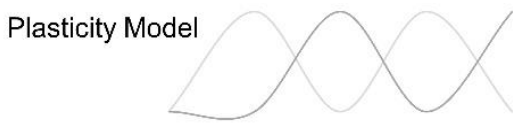

(a)
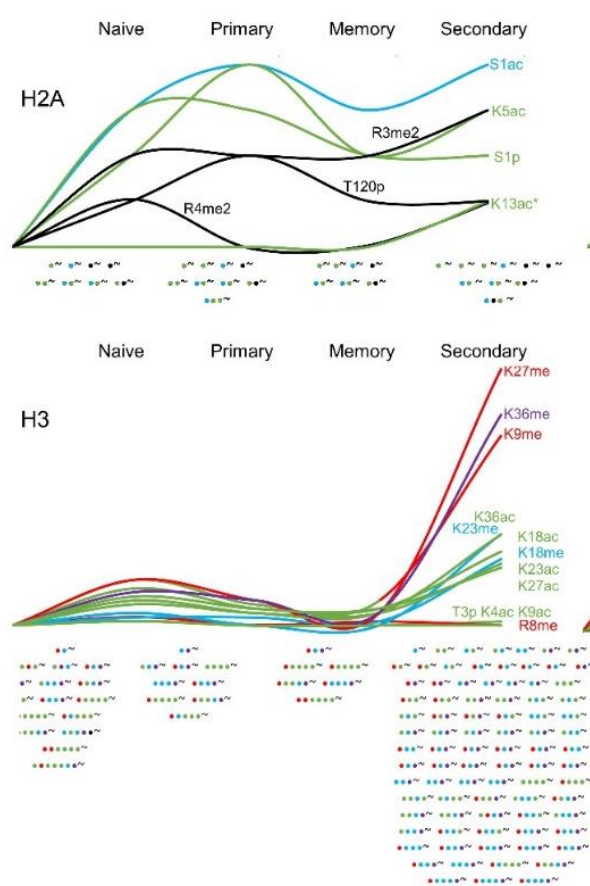

(c)
Linear Model

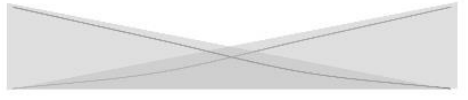

(b)
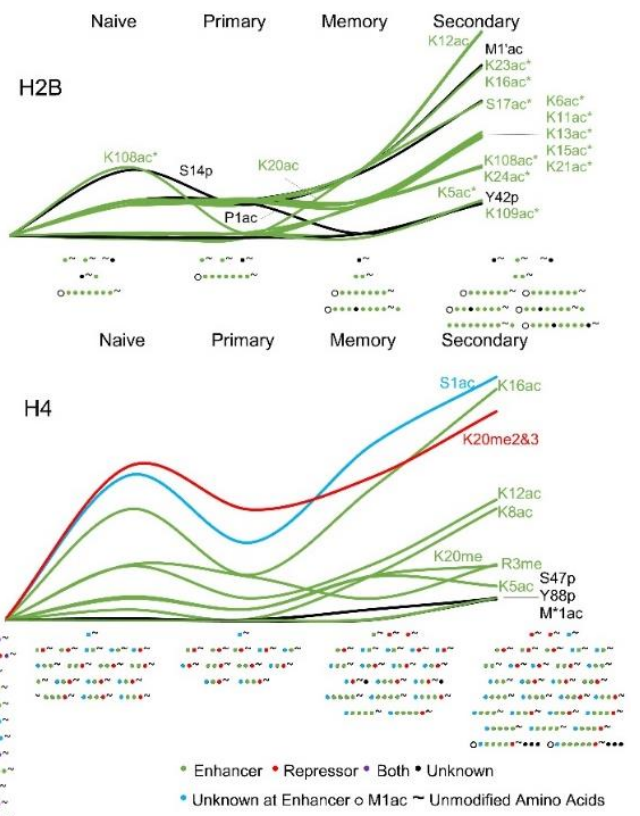

Figure 5. Patterns of histone PTMs over time with CD8 T cell differentiation after influenza infection. $\mathrm{T}$ cells have unique histone PTMs that are thought to form based on two models of $\mathrm{T}$ cell differentiation. (a) In the plasticity model, combinations of PTMs oscillate in on and off patterns as T cells progress through differentiation. In this case, the naïve T cells are activated and differentiate into effector T cells in the primary infection and are either terminally differentiated and contract or form Tm that are activated in the secondary infection and follow the same cycle. In this model, the PTMs cycle in on and off and on patterns regulating similar patterns of transcription. (b) In the linear differentiation model, $\mathrm{T}$ cell progression from naïve to primary or memory is mediated by the persistence and magnitude of antigenic stimulation. Effector cells that are not fully differentiated when the activation signal wains remain as memory cells in a transitory state of mixed on or off signals that are driven in one direction or the other in the secondary infection. In this model, there is a progressive gain or loss of enhancing and repressing PTMs. (c) The presence of individual PTMs in the identified proteoforms was tallied for each T cell subset and graphed. Below the x-axis, each unique combination of PTMs is represented per naïve, primary, memory, and secondary states. PTMs are presented as circles, and the tilde symbol $(\sim)$ indicates unmodified stretches of amino acids. Circles to the left of the tilde are in the amino-terminal histone tails, and on the right are at the carboxy terminus of the histone.

The circular or oscillation model fit for repressive modifications H3 R8me and H4 K20me, which had on-off-on-off and high-low-high-low prevalence, respectively. Similarly, H4 S1ac and the activators H4 K12ac and K16ac oscillated from high to low to high in Tn, Teff ${ }^{1}$ and Tm, respectively, and remained high in Teff ${ }^{2}$ (Figure 5c). The methylations of H4 R3 and H3 K27 and K36 were detected 
less frequently in Tm, resulting in Tn, Teff ${ }^{1}$, Tm, and Teff ${ }^{2}$ following a high-high-low-highest pattern (Figure 5c). Following the linear accumulation model, some PTMs were acquired with memory and maintained or increased prevalence in the secondary response (H2B K5ac, K11ac, K15ac, and K20ac and H4 S47p and Y88p) (Figure 5c). These were often associated with neighboring modifications that were present at low levels in Tn and Teff ${ }^{1}$ but increased at the memory stage (e.g., H2B K12ac, K16ac, and K23ac and H4 K5ac and K20me). Acetylation of lysine 13 and 109 was detected on H2A and H2B only in the Teff", as was phosphorylation of H2B Y42 and H4 S1 and Y51 (Figure 5c). Acetylation of lysine $6,13,17$, and 24 on H2B was only detected on one proteoform until the secondary response when it was detected in several PTMs combinations. Methylation of K18 on H3 followed a similar trend. Modifications that did not fit these models may have been influenced by the heterogeneity of the Tn and Teff ${ }^{2}$ populations. For example, a few modifications were detected exclusively in the Tn and Teff ${ }^{2}$ (i.e., H2A R4me2 and H3T3p, and K23me). All the acetylations to the mid-region of the amino-terminal tail of H3 (i.e., K18-36) occurred at a higher frequency in Tn and Teff ${ }^{2}$. Methylation of $\mathrm{K} 9$ on $\mathrm{H} 3$, a repressor, also followed this pattern (Figure $5 \mathrm{c}$ ). Interestingly, the opposing activating acetylation of this lysine and nearby lysine 4 was only detected in naïve T cells, and these were the only PTMs that were unique to this subset.

This study is limited in that it does not relate these modifications to gene expression. Instead, it provides the identity and abundance information for specific histone modifications and their combination per proteoform in T cell subsets isolated from mice over the course of influenza infection. The high-level analysis summarized in Figure 5 supports the current models that attempt to integrate epigenetics into $\mathrm{T}$ cell differentiation paradigms. Previously, these models integrated naïve T cells with $\mathrm{T}$ effector cells in the primary response and Tm subsets. Here we provide additional clarity on the epigenetic programming of Teff in the secondary response. However, these were bulk $\mathrm{T}$ cell populations within each subset as we were unable to purify enough histones from antigen-specific T cells to compare across groups (DNS). In lieu of tetramer staining, we employed a gating strategy to increased influenza-specific populations in the BAL, lung and spleen [10]. In the primary response, influenza-specific CD8 T cells are the dominant population. Due to the five dominant epitopes shared between X31 and PR8, it is even higher in the secondary response (between 70 and 90\%) $[10,88,139]$. $\mathrm{T}$ cell heterogeneity may contribute to the higher accumulation of a unique combination of $\mathrm{H} 3$ and $\mathrm{H} 4$ PTMs in Teff ${ }^{2}$ (Figure 5c). However, T cell heterogeneity in the naïve population is much higher than either Teff ${ }^{1}$ or Teff $^{2}$, and the histone PTMs diversity from Tn is lower than Teff ${ }^{2}$. Thus, it is unlikely heterogeneity of Teff ${ }^{2}$ accounts for the diversity in the histone proteoforms. It is feasible these PTMs combinations contribute to the enforcement of terminal differentiation.

We concede these data may not be generalizable to discreet subpopulations within each compartment. Nonetheless, the permissive and repressive marks appear to be maintained in the generation of daughter cells from the memory pool and increased in the secondary response. Perhaps the most notable of these were the group of H2B and H4 PTMs mentioned above that were either acquired or increased in Tm and sustained Teff? . Consistent with previous reports [140], we saw a decommissioning of some naïve enhancer PTMs as well as the generation of new enhancers in Teff ${ }^{1}$ and Teff ${ }^{2}$ (Figure $5 \mathrm{c}$ ). Like previous reports, the $\mathrm{H} 3$ modifications we identified in Tm were bivalent. We expected to see a loss of repressor signals with a gain of enhancers in Teff ${ }^{2}$. Instead, we saw an increase in some repressors and a significant increase in enhancer marks in Teff ${ }^{2}$ (Figure 5). In the case of H3K9 methylation, this makes good sense as it is associated with the short life span of CD8 effector cells [141]. The bulk of what is known relating gene expression patterns to histone modification in $\mathrm{T}$ cell subsets centers around H3K4me3 and H3K27me3. We did not detect H3K4me3, yet our data suggest other combinations and modifications may be worth exploring. Indeed, in the studies mentioned above, gene expression did not always correlate with H3K4me3 and H3K27me3 patterns and appear to be best associated in terms of H3K4me3 at effector loci in Teff ${ }^{1}[17,18,81,142,143]$. This suggests other mechanisms may be influential in maintaining epigenetic programming throughout the stages of $\mathrm{T}$ cell differentiation and recent research in this area indicates even minor changes in highly conserved 
regions alter chromatin structure and gene regulation [144,145]. One possibility is that unique PTM combinations, especially those including understudied modifications that block or induce regional modifications, act as tuning mechanisms or overriding signals that functionally contribute to the role of the histone code in controlling $\mathrm{T}$ cell fate.

Due to their high heterogeneity, histones are inherently challenging to study. In addition, interpreting combinations of histone PTMs is difficult because of the lack of knowledge regarding their biological function [146-148]. However, our identification of these differentially marked histones in unique combinations from distinct locations and $\mathrm{T}$ cell subsets raises several important questions. First, are microenvironmental conditions influencing $\mathrm{T}$ cell epigenetics and is this functionally relevant? Second, are the combinations of histone PTMs we identified controlling gene expression in the T cell response, or do they play other currently undefined roles such as regulating regional modifications? If the former is true, PTMs may act to fine-tune canonical modifications or function independently. Third, are the modifications acquired with memory and sustained in the secondary response mediating memory cell survival or necessary for homeostatic proliferation upon recall? HiPTMap of activated versus naïve $\mathrm{T}$ cells subsets and effector subsets across locations acquired from the same groups of mice as well as the comparison of $\mathrm{T}$ cells over time following influenza infection has provided the blueprint to answer some of these questions and will likely contribute to our understanding of epigenetic regulation of $\mathrm{T}$ cell biology.

\section{Conclusions}

The HiPTMap strategy used here enhances proteoform identification, providing a comprehensive analysis. Our results show the high potential of online nanoflow 1D and 2DLC separations for top-down analysis of histones and HiPTMap strategy. In addition, this platform extended the dynamic range of MS measurements, increasing the number of confidently identified histone proteoforms compared to 1D LC-MS approach. With this strategy, we identified hundreds of unique histone-modified species isolated from mice following influenza infection. As a result, we now know that several new bivalent combinations are present in effector T cells; the histone map changes as T cells relocate during influenza infection; and the secondary recall response of CD8 T cells induces a significant increase in histone PTMs associated with transcriptional activation. These histone modifications appear to oscillate or accumulate over the course of T cell differentiation in a PTMs specific manor. Recent advancements in top-down technology will facilitate more confident and comprehensive histone proteoform characterization and enable us to approach (near) single-cell sized samples to better address cell heterogeneity challenge. Furthermore, computational approaches are rapidly advancing $[48,149,150]$, and we anticipate even more detailed data-mining to be achieved from HiPTMap with the analysis that will result in the discovery of interdependent relationships between unique modified forms identified here and reported elsewhere to decipher the histone code.

Supplementary Materials: The following are available online at http:/www.mdpi.com/1999-4915/12/12/1409/s1, Table S1: Modified core histone proteoforms identified in Tn and activated CD8 T cells. Table S2: Relative abundance of histone modifications from naïve and activated CD8 T-cells. File S1: Summary LC-MS data of T cell subsets after primary and secondary influenza infection. File S2: Summary LC-MS data of histones from activated CD8 T cells from the spleen, BAL, and lung after influenza infection.

Author Contributions: Conceptualization, L.P.-T. and H.S.S.; data curation, S.R., Z.T., S.W. and S.H.; formal analysis, Z.T., S.W. and S.H.; investigation, H.S.S.; methodology, Z.T. and L.P.-T.; project administration, L.P.-T.; resources, L.P.-T. and H.S.S.; software, supervision, H.S.S.; validation, S.W. and S.H.; writing-original draft, S.R. and H.S.S.; writing-review and editing, S.R., L.P.-T. and H.S.S. All authors have read and agreed to the published version of the manuscript.

Funding: This research was funded by the Le Bonheur Young Investigator Award and the Children's Foundation Research Institute, Memphis, Tennessee, USA (H.S.S.).

Acknowledgments: The authors wish to thank Matthew E. Monroe of Pacific Northwest National Laboratory for assembling these data and Courtney Bricker-Anthony of the Children's Foundation Research Institute for scientific editing. 
Conflicts of Interest: The authors declare no conflict of interest. The funders had no role in the design of the study; in the collection, analyses, or interpretation of data; in the writing of the manuscript, or in the decision to publish the results.

\section{References}

1. Turner, S.J.; Kedzierska, K.; La Gruta, N.L.; Webby, R.; Doherty, P.C. Characterization of CD8+ T cell repertoire diversity and persistence in the influenza A virus model of localized, transient infection. Semin. Immunol. 2004, 16, 179-184. [CrossRef] [PubMed]

2. La Gruta, N.L.; Turner, S.J.; Doherty, P.C. Hierarchies in cytokine expression profiles for acute and resolving influenza virus-specific CD8+ T cell responses: Correlation of cytokine profile and TCR avidity. J. Immunol. 2004, 172, 5553-5560. [CrossRef] [PubMed]

3. Russ, B.E.; Olshanksy, M.; Smallwood, H.S.; Li, J.; Denton, A.E.; Prier, J.E.; Stock, A.T.; Croom, H.A.; Cullen, J.G.; Nguyen, M.L.; et al. Distinct epigenetic signatures delineate transcriptional programs during virus-specific CD8(+) T cell differentiation. Immunity 2014, 41, 853-865. [CrossRef]

4. Duan, S.; Thomas, P.G. Balancing Immune Protection and Immune Pathology by CD8(+) T-Cell Responses to Influenza Infection. Front. Immunol. 2016, 7, 25. [CrossRef]

5. Duan, S.; Meliopoulos, V.A.; McClaren, J.L.; Guo, X.Z.; Sanders, C.J.; Smallwood, H.S.; Webby, R.J.; Schultz-Cherry, S.L.; Doherty, P.C.; Thomas, P.G. Diverse heterologous primary infections radically alter immunodominance hierarchies and clinical outcomes following H7N9 influenza challenge in mice. PLoS Pathogens. 2015, 11, e1004642. [CrossRef]

6. Veiga-Fernandes, H.; Walter, U.; Bourgeois, C.; McLean, A.; Rocha, B. Response of naive and memory CD8+ T cells to antigen stimulation in vivo. Nat. Immunol. 2000, 1, 47-53. [CrossRef]

7. Kaech, S.M.; Hemby, S.; Kersh, E.; Ahmed, R. Molecular and functional profiling of memory CD8 T cell differentiation. Cell 2002, 111, 837-851. [CrossRef]

8. Pizzolla, A.; Nguyen, T.H.; Sant, S.; Jaffar, J.; Loudovaris, T.; Mannering, S.I.; Thomas, P.G.; Westall, G.P.; Kedzierska, K.; Wakim, L.M. Influenza-specific lung-resident memory $\mathrm{T}$ cells are proliferative and polyfunctional and maintain diverse TCR profiles. J. Clin. Investig. 2018, 128, 721-733. [CrossRef]

9. Andreansky, S.S.; Stambas, J.; Thomas, P.G.; Xie, W.; Webby, R.J.; Doherty, P.C. Consequences of immunodominant epitope deletion for minor influenza virus-specific CD8+-T-cell responses. J. Virol. 2005, 79, 4329-4339. [CrossRef]

10. Keating, R.; Morris, M.Y.; Yue, W.; Reynolds, C.E.; Harris, T.L.; Brown, S.A.; Doherty, P.C.; Thomas, P.G.; McGargill, M.A. Potential killers exposed: Tracking endogenous influenza-specific CD8(+) T cells. Immunol. Cell Biol. 2018, 96, 1104-1119. [CrossRef]

11. Souquette, A.; Thomas, P.G. Past Life and Future Effects-How Heterologous Infections Alter Immunity to Influenza Viruses. Front. Immunol. 2018, 9, 1071. [CrossRef]

12. Kannan, A.; Huang, W.; Huang, F.; August, A. Signal transduction via the T cell antigen receptor in naive and effector/memory T cells. Int. J. Biochem. Cell Biol. 2012, 44, 2129-2134. [CrossRef]

13. Ghoneim, H.E.; Fan, Y.; Moustaki, A.; Abdelsamed, H.A.; Dash, P.; Dogra, P.; Carter, R.; Awad, W.; Neale, G.; Thomas, P.G.; et al. De Novo Epigenetic Programs Inhibit PD-1 Blockade-Mediated T Cell Rejuvenation. Cell 2017, 170, 142-157.e119. [CrossRef]

14. Abdelsamed, H.A.; Zebley, C.C.; Youngblood, B. Epigenetic Maintenance of Acquired Gene Expression Programs during Memory CD8 T Cell Homeostasis. Front. Immunol. 2018, 9, 6. [CrossRef]

15. Youngblood, B.; Noto, A.; Porichis, F.; Akondy, R.S.; Ndhlovu, Z.M.; Austin, J.W.; Bordi, R.; Procopio, F.A.; Miura, T.; Allen, T.M.; et al. Cutting edge: Prolonged exposure to HIV reinforces a poised epigenetic program for PD-1 expression in virus-specific CD8 T cells. J. Immunol. 2013, 191, 540-544. [CrossRef]

16. Harland, K.L.; Day, E.B.; Apte, S.H.; Russ, B.E.; Doherty, P.C.; Turner, S.J.; Kelso, A. Epigenetic plasticity of Cd8a locus during CD8(+) T-cell development and effector differentiation and reprogramming. Nat. Commun. 2014, 5, 3547. [CrossRef]

17. Denton, A.E.; Russ, B.E.; Doherty, P.C.; Rao, S.; Turner, S.J. Differentiation-dependent functional and epigenetic landscapes for cytokine genes in virus-specific CD8+ T cells. Proc. Natl. Acad. Sci. USA 2011, 108, 15306-15311. [CrossRef] 
18. Juelich, T.; Sutcliffe, E.L.; Denton, A.; He, Y.; Doherty, P.C.; Parish, C.R.; Turner, S.J.; Tremethick, D.J.; Rao, S. Interplay between chromatin remodeling and epigenetic changes during lineage-specific commitment to granzyme B expression. J. Immunol. 2009, 183, 7063-7072. [CrossRef]

19. Smith, L.M.; Kelleher, N.L.; The Consortium for Top Down Proteomics. Proteoform: A single term describing protein complexity. Nat. Methods 2013, 10, 186-187. [CrossRef]

20. Wu, J.I.; Lessard, J.; Crabtree, G.R. Understanding the words of chromatin regulation. Cell 2009, 136, $200-206$. [CrossRef]

21. Kelly, T.K.; De Carvalho, D.D.; Jones, P.A. Epigenetic modifications as therapeutic targets. Nat. Biotechnol. 2010, 28, 1069-1078. [CrossRef] [PubMed]

22. Sadakierska-Chudy, A.; Filip, M. A comprehensive view of the epigenetic landscape. Part II: Histone post-translational modification, nucleosome level, and chromatin regulation by ncRNAs. Neurotox Res. 2015, 27, 172-197. [CrossRef] [PubMed]

23. Burgess, R.J.; Zhang, Z. Histone chaperones in nucleosome assembly and human disease. Nat. Struct. Mol. Biol. 2013, 20, 14-22. [CrossRef] [PubMed]

24. Eberharter, A.; Becker, P.B. Histone acetylation: A switch between repressive and permissive chromatin. Second Rev. Ser. Chromatin Dyn. Embo Rep. 2002, 3, 224-229. [CrossRef] [PubMed]

25. Stengel, K.R.; Zhao, Y.; Klus, N.J.; Kaiser, J.F.; Gordy, L.E.; Joyce, S.; Hiebert, S.W.; Summers, A.R. Histone Deacetylase 3 Is Required for Efficient T Cell Development. Mol. Cell Biol. 2015, 35, 3854-3865. [CrossRef]

26. Dovey, O.M.; Foster, C.T.; Conte, N.; Edwards, S.A.; Edwards, J.M.; Singh, R.; Vassiliou, G.; Bradley, A.; Cowley, S.M. Histone deacetylase 1 and 2 are essential for normal T-cell development and genomic stability in mice. Blood 2013, 121, 1335-1344. [CrossRef]

27. Heideman, M.R.; Wilting, R.H.; Yanover, E.; Velds, A.; de Jong, J.; Kerkhoven, R.M.; Jacobs, H.; Wessels, L.F.; Dannenberg, J.H. Dosage-dependent tumor suppression by histone deacetylases 1 and 2 through regulation of c-Myc collaborating genes and p53 function. Blood 2013, 121, 2038-2050. [CrossRef]

28. Xiao, H.; Jiao, J.; Wang, L.; O’Brien, S.; Newick, K.; Wang, L.C.; Falkensammer, E.; Liu, Y.; Han, R.; Kapoor, V.; et al. HDAC5 controls the functions of Foxp3(+) T-regulatory and CD8(+) T cells. Int. J. Cancer 2016, 138, 2477-2486. [CrossRef]

29. Tsuji, G.; Okiyama, N.; Villarroel, V.A.; Katz, S.I. Histone deacetylase 6 inhibition impairs effector CD8 T-cell functions during skin inflammation. J. Allergy Clin. Immunol. 2015, 135, 1228-1239. [CrossRef]

30. Nunez-Andrade, N.; Iborra, S.; Trullo, A.; Moreno-Gonzalo, O.; Calvo, E.; Catalan, E.; Menasche, G.; Sancho, D.; Vazquez, J.; Yao, T.P.; et al. HDAC6 regulates the dynamics of lytic granules in cytotoxic T lymphocytes. J. Cell Sci. 2016, 129, 1305-1311. [CrossRef]

31. Tschismarov, R.; Firner, S.; Gil-Cruz, C.; Goschl, L.; Boucheron, N.; Steiner, G.; Matthias, P.; Seiser, C.; Ludewig, B.; Ellmeier, W. HDAC1 controls CD8+ T cell homeostasis and antiviral response. PLoS ONE 2014, 9, e110576. [CrossRef] [PubMed]

32. Exner, V.; Aichinger, E.; Shu, H.; Wildhaber, T.; Alfarano, P.; Caflisch, A.; Gruissem, W.; Kohler, C.; Hennig, L. The chromodomain of LIKE HETEROCHROMATIN PROTEIN 1 is essential for H3K27me3 binding and function during Arabidopsis development. PLoS ONE 2009, 4, e5335. [CrossRef] [PubMed]

33. Hansen, K.H.; Bracken, A.P.; Pasini, D.; Dietrich, N.; Gehani, S.S.; Monrad, A.; Rappsilber, J.; Lerdrup, M.; Helin, K. A model for transmission of the H3K27me3 epigenetic mark. Nat. Cell Biol. 2008, 10, 1291-1300. [CrossRef] [PubMed]

34. van Dijk, K.; Marley, K.E.; Jeong, B.R.; Xu, J.; Hesson, J.; Cerny, R.L.; Waterborg, J.H.; Cerutti, H. Monomethyl histone $\mathrm{H} 3$ lysine 4 as an epigenetic mark for silenced euchromatin in Chlamydomonas. Plant Cell 2005, 17, 2439-2453. [CrossRef]

35. Nightingale, K.P.; Gendreizig, S.; White, D.A.; Bradbury, C.; Hollfelder, F.; Turner, B.M. Cross-talk between histone modifications in response to histone deacetylase inhibitors: MLL4 links histone H3 acetylation and histone H3K4 methylation. J. Biol. Chem. 2007, 282, 4408-4416. [CrossRef]

36. Taverna, S.D.; Ilin, S.; Rogers, R.S.; Tanny, J.C.; Lavender, H.; Li, H.; Baker, L.; Boyle, J.; Blair, L.P.; Chait, B.T.; et al. Yng1 PHD finger binding to H3 trimethylated at K4 promotes NuA3 HAT activity at K14 of $\mathrm{H} 3$ and transcription at a subset of targeted ORFs. Mol. Cell 2006, 24, 785-796. [CrossRef]

37. Roh, T.Y.; Cuddapah, S.; Cui, K.; Zhao, K. The genomic landscape of histone modifications in human T cells. Proc. Natl. Acad. Sci. USA 2006, 103, 15782-15787. [CrossRef] 
38. Akkers, R.C.; van Heeringen, S.J.; Jacobi, U.G.; Janssen-Megens, E.M.; Francoijs, K.J.; Stunnenberg, H.G.; Veenstra, G.J. A hierarchy of H3K4me3 and H3K27me3 acquisition in spatial gene regulation in Xenopus embryos. Dev. Cell 2009, 17, 425-434. [CrossRef]

39. de la Paz Sanchez, M.; Gutierrez, C. Arabidopsis ORC1 is a PHD-containing H3K4me3 effector that regulates transcription. Proc. Natl. Acad. Sci. USA 2009, 106, 2065-2070. [CrossRef]

40. Strahl, B.D.; Allis, C.D. The language of covalent histone modifications. Nature 2000, 403, 41-45. [CrossRef]

41. He, S.; Tong, Q.; Bishop, D.K.; Zhang, Y. Histone methyltransferase and histone methylation in inflammatory T-cell responses. Immunotherapy 2013, 5, 989-1004. [CrossRef] [PubMed]

42. Bernstein, B.E.; Mikkelsen, T.S.; Xie, X.; Kamal, M.; Huebert, D.J.; Cuff, J.; Fry, B.; Meissner, A.; Wernig, M.; Plath, K.; et al. A bivalent chromatin structure marks key developmental genes in embryonic stem cells. Cell 2006, 125, 315-326. [CrossRef] [PubMed]

43. Stock, J.K.; Giadrossi, S.; Casanova, M.; Brookes, E.; Vidal, M.; Koseki, H.; Brockdorff, N.; Fisher, A.G.; Pombo, A. Ring1-mediated ubiquitination of H2A restrains poised RNA polymerase II at bivalent genes in mouse ES cells. Nat. Cell Biol. 2007, 9, 1428-1435. [CrossRef]

44. Jorgensen, H.F.; Azuara, V.; Amoils, S.; Spivakov, M.; Terry, A.; Nesterova, T.; Cobb, B.S.; Ramsahoye, B.; Merkenschlager, M.; Fisher, A.G. The impact of chromatin modifiers on the timing of locus replication in mouse embryonic stem cells. Genome Biol. 2007, 8, R169. [CrossRef]

45. Ueberheide, B.M.; Mollah, S. Deciphering the histone code using mass spectrometry. Int. J. Mass Spectrom. 2007, 259, 46-56. [CrossRef]

46. Keating, R.; Hertz, T.; Wehenkel, M.; Harris, T.L.; Edwards, B.A.; McClaren, J.L.; Brown, S.A.; Surman, S.; Wilson, Z.S.; Bradley, P.; et al. The kinase mTOR modulates the antibody response to provide cross-protective immunity to lethal infection with influenza virus. Nat. Immunol. 2013, 14, 1266-1276. [CrossRef]

47. Tian, Z.; Tolić, N.; Zhao, R.; Moore, R.J.; Hengel, S.M.; Robinson, E.W.; Stenoien, D.L.; Wu, S.; Smith, R.D.; Paša-Tolić, L. Enhanced top-down characterization of histone post-translational modifications. Genome Biol. 2012, 13, R86. [CrossRef]

48. Karch, K.R.; Sidoli, S.; Garcia, B.A. Identification and Quantification of Histone PTMs Using High-Resolution Mass Spectrometry. Methods Enzymol. 2016, 574, 3-29. [CrossRef]

49. DiMaggio, P.A., Jr.; Young, N.L.; Baliban, R.C.; Garcia, B.A.; Floudas, C.A. A mixed integer linear optimization framework for the identification and quantification of targeted post-translational modifications of highly modified proteins using multiplexed electron transfer dissociation tandem mass spectrometry. Mol. Cell. Proteom. MCP 2009, 8, 2527-2543. [CrossRef]

50. Guan, S.; Burlingame, A.L. Data processing algorithms for analysis of high resolution MSMS spectra of peptides with complex patterns of posttranslational modifications. Mol. Cell. Proteom. Mcp 2010, 9, 804-810. [CrossRef]

51. Frank, A.M.; Pesavento, J.J.; Mizzen, C.A.; Kelleher, N.L.; Pevzner, P.A. Interpreting top-down mass spectra using spectral alignment. Anal. Chem. 2008, 80, 2499-2505. [CrossRef]

52. Smallwood, H.S.; Duan, S.; Morfouace, M.; Rezinciuc, S.; Shulkin, B.L.; Shelat, A.; Zink, E.E.; Milasta, S.; Bajracharya, R.; Oluwaseum, A.J.; et al. Targeting Metabolic Reprogramming by Influenza Infection for Therapeutic Intervention. Cell Rep. 2017, 19, 1640-1653. [CrossRef]

53. Grant, P.A.; Eberharter, A.; John, S.; Cook, R.G.; Turner, B.M.; Workman, J.L. Expanded lysine acetylation specificity of Gcn5 in native complexes. J. Biol. Chem. 1999, 274, 5895-5900. [CrossRef]

54. Zhao, Y.; Garcia, B.A. Comprehensive Catalog of Currently Documented Histone Modifications. Cold Spring Harb. Perspect Biol. 2015, 7, a025064. [CrossRef]

55. Tamaru, H.; Selker, E.U. A histone H3 methyltransferase controls DNA methylation in Neurospora crassa. Nature 2001, 414, 277-283. [CrossRef]

56. Johnson, L.; Cao, X.; Jacobsen, S. Interplay between two epigenetic marks. DNA methylation and histone H3 lysine 9 methylation. Curr. Biol. 2002, 12, 1360-1367. [CrossRef]

57. Barber, C.M.; Turner, F.B.; Wang, Y.; Hagstrom, K.; Taverna, S.D.; Mollah, S.; Ueberheide, B.; Meyer, B.J.; Hunt, D.F.; Cheung, P.; et al. The enhancement of histone H4 and H2A serine 1 phosphorylation during mitosis and S-phase is evolutionarily conserved. Chromosoma 2004, 112, 360-371. [CrossRef]

58. Zhang, Y.; Griffin, K.; Mondal, N.; Parvin, J.D. Phosphorylation of histone H2A inhibits transcription on chromatin templates. J. Biol. Chem. 2004, 279, 21866-21872. [CrossRef] 
59. Caterino, T.L.; Hayes, J.J. Structure of the H1 C-terminal domain and function in chromatin condensation. Biochem. Cell Biol. 2011, 89, 35-44. [CrossRef]

60. Rossetto, D.; Avvakumov, N.; Cote, J. Histone phosphorylation: A chromatin modification involved in diverse nuclear events. Epigenetics 2012, 7, 1098-1108. [CrossRef]

61. Clarke, A.S.; Lowell, J.E.; Jacobson, S.J.; Pillus, L. Esa1p is an essential histone acetyltransferase required for cell cycle progression. Mol. Cell Biol. 1999, 19, 2515-2526. [CrossRef]

62. Kimura, A.; Horikoshi, M. Tip60 acetylates six lysines of a specific class in core histones in vitro. Genes Cells 1998, 3, 789-800. [CrossRef]

63. Schiltz, R.L.; Mizzen, C.A.; Vassilev, A.; Cook, R.G.; Allis, C.D.; Nakatani, Y. Overlapping but distinct patterns of histone acetylation by the human coactivators p300 and PCAF within nucleosomal substrates. J. Biol. Chem. 1999, 274, 1189-1192. [CrossRef]

64. Verreault, A.; Kaufman, P.D.; Kobayashi, R.; Stillman, B. Nucleosomal DNA regulates the core-histone-binding subunit of the human Hat1 acetyltransferase. Curr. Biol. 1998, 8, 96-108. [CrossRef]

65. Aihara, H.; Nakagawa, T.; Mizusaki, H.; Yoneda, M.; Kato, M.; Doiguchi, M.; Imamura, Y.; Higashi, M.; Ikura, T.; Hayashi, T.; et al. Histone H2A T120 Phosphorylation Promotes Oncogenic Transformation via Upregulation of Cyclin D1. Mol. Cell 2016, 64, 176-188. [CrossRef]

66. Zhang, M.; Liang, C.; Chen, Q.; Yan, H.; Xu, J.; Zhao, H.; Yuan, X.; Liu, J.; Lin, S.; Lu, W.; et al. Histone H2A phosphorylation recruits topoisomerase Ilalpha to centromeres to safeguard genomic stability. EMBO J. 2020, 39, e101863. [CrossRef]

67. Füllgrabe, J.; Hajji, N.; Joseph, B. Cracking the death code: Apoptosis-related histone modifications. Cell Death Differ. 2010, 17, 1238-1243. [CrossRef]

68. Beck, H.C.; Nielsen, E.C.; Matthiesen, R.; Jensen, L.H.; Sehested, M.; Finn, P.; Grauslund, M.; Hansen, A.M.; Jensen, O.N. Quantitative Proteomic Analysis of Post-translational Modifications of Human Histones. Mol. Cell. Proteom. 2006, 5, 1314-1325. [CrossRef]

69. Zhang, L.; Eugeni, E.E.; Parthun, M.R.; Freitas, M.A. Identification of novel histone post-translational modifications by peptide mass fingerprinting. Chromosoma 2003, 112, 77-86. [CrossRef]

70. Kim, S.C.; Sprung, R.; Chen, Y.; Xu, Y.; Ball, H.; Pei, J.; Cheng, T.; Kho, Y.; Xiao, H.; Xiao, L.; et al. Substrate and functional diversity of lysine acetylation revealed by a proteomics survey. Mol. Cell 2006, 23, 607-618. [CrossRef]

71. Wisniewski, J.R.; Zougman, A.; Mann, M. Nepsilon-formylation of lysine is a widespread post-translational modification of nuclear proteins occurring at residues involved in regulation of chromatin function. Nucleic Acids Res. 2008, 36, 570-577. [CrossRef]

72. Cheng, J.; Blum, R.; Bowman, C.; Hu, D.; Shilatifard, A.; Shen, S.; Dynlacht, B.D. A role for H3K4 monomethylation in gene repression and partitioning of chromatin readers. Mol. Cell 2014, 53, 979-992. [CrossRef] [PubMed]

73. Briggs, S.D.; Bryk, M.; Strahl, B.D.; Cheung, W.L.; Davie, J.K.; Dent, S.Y.; Winston, F.; Allis, C.D. Histone H3 lysine 4 methylation is mediated by Set1 and required for cell growth and rDNA silencing in Saccharomyces cerevisiae. Genes Dev. 2001, 15, 3286-3295. [CrossRef] [PubMed]

74. Nakamura, T.; Mori, T.; Tada, S.; Krajewski, W.; Rozovskaia, T.; Wassell, R.; Dubois, G.; Mazo, A.; Croce, C.M.; Canaani, E. ALL-1 is a histone methyltransferase that assembles a supercomplex of proteins involved in transcriptional regulation. Mol. Cell 2002, 10, 1119-1128. [CrossRef]

75. Zhang, X.; Bernatavichute, Y.V.; Cokus, S.; Pellegrini, M.; Jacobsen, S.E. Genome-wide analysis of mono-, diand trimethylation of histone H3 lysine 4 in Arabidopsis thaliana. Genome Biol. 2009, 10, R62. [CrossRef] [PubMed]

76. Pace, L.; Goudot, C.; Zueva, E.; Gueguen, P.; Burgdorf, N.; Waterfall, J.J.; Quivy, J.-P.; Almouzni, G.; Amigorena, $\mathrm{S}$. The epigenetic control of stemness in $\mathrm{CD}^{+} \mathrm{T}$ cell fate commitment. Science 2018, 359, 177-186. [CrossRef] [PubMed]

77. Ruenjaiman, V.; Butta, P.; Leu, Y.W.; Pongpanich, M.; Leelahavanichkul, A.; Kueanjinda, P.; Palaga, T. Profile of Histone H3 Lysine 4 Trimethylation and the Effect of Lipopolysaccharide/Immune Complex-Activated Macrophages on Endotoxemia. Front. Immunol. 2019, 10, 2956. [CrossRef]

78. Chen, S.; Yang, J.; Wei, Y.; Wei, X. Epigenetic regulation of macrophages: From homeostasis maintenance to host defense. Cell Mol. Immunol 2020, 17, 36-49. [CrossRef] 
79. Wei, G.; Wei, L.; Zhu, J.; Zang, C.; Hu-Li, J.; Yao, Z.; Cui, K.; Kanno, Y.; Roh, T.Y.; Watford, W.T.; et al. Global mapping of $\mathrm{H} 3 \mathrm{~K} 4 \mathrm{me} 3$ and $\mathrm{H} 3 \mathrm{~K} 27 \mathrm{me} 3$ reveals specificity and plasticity in lineage fate determination of differentiating CD4+ T cells. Immunity 2009, 30, 155-167. [CrossRef]

80. LaMere, S.A.; Thompson, R.C.; Meng, X.; Komori, H.K.; Mark, A.; Salomon, D.R. H3K27 Methylation Dynamics during CD4 T Cell Activation: Regulation of JAK/STAT and IL12RB2 Expression by JMJD3. J. Immunol. 2017, 199, 3158-3175. [CrossRef]

81. Araki, Y.; Wang, Z.; Zang, C.; Wood, W.H., 3rd; Schones, D.; Cui, K.; Roh, T.Y.; Lhotsky, B.; Wersto, R.P.; Peng, W.; et al. Genome-wide analysis of histone methylation reveals chromatin state-based regulation of gene transcription and function of memory CD8+ T cells. Immunity 2009, 30, 912-925. [CrossRef]

82. Chang, S.; Aune, T.M. Dynamic changes in histone-methylation 'marks' across the locus encoding interferon-gamma during the differentiation of T helper type 2 cells. Nat. Immunol. 2007, 8, 723-731. [CrossRef] [PubMed]

83. van der Merwe, M.M.; Smith, J.E. The community health nurse in the next decades. Nurs. RSA 1991, 6, 38-41. [PubMed]

84. Chen, X.; Wang, J.; Woltring, D.; Gerondakis, S.; Shannon, M.F. Histone dynamics on the interleukin-2 gene in response to T-cell activation. Mol. Cell Biol. 2005, 25, 3209-3219. [CrossRef] [PubMed]

85. Schiza, V.; Molina-Serrano, D.; Kyriakou, D.; Hadjiantoniou, A.; Kirmizis, A. N-alpha-terminal acetylation of histone $\mathrm{H} 4$ regulates arginine methylation and ribosomal DNA silencing. PLoS Genet. 2013, 9, e1003805. [CrossRef] [PubMed]

86. Ju, J.; Chen, A.; Deng, Y.; Liu, M.; Wang, Y.; Wang, Y.; Nie, M.; Wang, C.; Ding, H.; Yao, B.; et al. NatD promotes lung cancer progression by preventing histone $\mathrm{H} 4$ serine phosphorylation to activate Slug expression. Nat. Commun. 2017, 8, 928. [CrossRef]

87. Olp, M.D.; Zhu, N.; Smith, B.C. Metabolically Derived Lysine Acylations and Neighboring Modifications Tune the Binding of the BET Bromodomains to Histone H4. Biochemistry 2017, 56, 5485-5495. [CrossRef]

88. Thomas, P.G.; Keating, R.; Hulse-Post, D.J.; Doherty, P.C. Cell-mediated protection in influenza infection. Emerg. Infect. Dis. 2006, 12, 48-54. [CrossRef]

89. Chew, Y.C.; Camporeale, G.; Kothapalli, N.; Sarath, G.; Zempleni, J. Lysine residues in N-terminal and C-terminal regions of human histone H2A are targets for biotinylation by biotinidase. J. Nutr. Biochem. 2006, 17, 225-233. [CrossRef]

90. Kothapalli, N.; Camporeale, G.; Kueh, A.; Chew, Y.C.; Oommen, A.M.; Griffin, J.B.; Zempleni, J. Biological functions of biotinylated histones. J. Nutr. Biochem. 2005, 16, 446-448. [CrossRef]

91. Odegard, V.H.; Kim, S.T.; Anderson, S.M.; Shlomchik, M.J.; Schatz, D.G. Histone modifications associated with somatic hypermutation. Immunity 2005, 23, 101-110. [CrossRef] [PubMed]

92. Molden, R.C.; Bhanu, N.V.; LeRoy, G.; Arnaudo, A.M.; Garcia, B.A. Multi-faceted quantitative proteomics analysis of histone H2B isoforms and their modifications. Epigenetics Chromatin 2015, 8, 15. [CrossRef] [PubMed]

93. Ruiz, P.D.; Gamble, M.J. MacroH2A1 chromatin specification requires its docking domain and acetylation of H2B lysine 20. Nat. Commun. 2018, 9, 5143. [CrossRef] [PubMed]

94. Creyghton, M.P.; Cheng, A.W.; Welstead, G.G.; Kooistra, T.; Carey, B.W.; Steine, E.J.; Hanna, J.; Lodato, M.A.; Frampton, G.M.; Sharp, P.A.; et al. Histone H3K27ac separates active from poised enhancers and predicts developmental state. Proc. Natl. Acad. Sci. USA 2010, 107, 21931-21936. [CrossRef]

95. Morris, S.A.; Rao, B.; Garcia, B.A.; Hake, S.B.; Diaz, R.L.; Shabanowitz, J.; Hunt, D.F.; Allis, C.D.; Lieb, J.D.; Strahl, B.D. Identification of histone H3 lysine 36 acetylation as a highly conserved histone modification. J. Biol. Chem. 2007, 282, 7632-7640. [CrossRef]

96. Beisel, C.; Imhof, A.; Greene, J.; Kremmer, E.; Sauer, F. Histone methylation by the Drosophila epigenetic transcriptional regulator Ash1. Nature 2002, 419, 857-862. [CrossRef]

97. Carter, J.E., Jr. Decreased heart rate variability in congestive heart failure. Am. J. Cardiol. 1992, 69, $286-287$. [CrossRef]

98. Daujat, S.; Bauer, U.M.; Shah, V.; Turner, B.; Berger, S.; Kouzarides, T. Crosstalk between CARM1 methylation and CBP acetylation on histone H3. Curr. Biol. 2002, 12, 2090-2097. [CrossRef]

99. Pal, S.; Vishwanath, S.N.; Erdjument-Bromage, H.; Tempst, P.; Sif, S. Human SWI/SNF-associated PRMT5 methylates histone $\mathrm{H} 3$ arginine 8 and negatively regulates expression of ST7 and NM23 tumor suppressor genes. Mol. Cell Biol. 2004, 24, 9630-9645. [CrossRef] 
100. Teoh, P.C.; Tan, L.K.; Chia, B.L.; Chao, T.C.; Tambyah, J.A.; Feng, P.H. Non-specific aorto-arteritis in Singapore with special reference to hypertension. Am. Heart J. 1978, 95, 683-690. [CrossRef]

101. Suka, N.; Suka, Y.; Carmen, A.A.; Wu, J.; Grunstein, M. Highly specific antibodies determine histone acetylation site usage in yeast heterochromatin and euchromatin. Mol. Cell 2001, 8, 473-479. [CrossRef]

102. Rea, S.; Eisenhaber, F.; O’Carroll, D.; Strahl, B.D.; Sun, Z.W.; Schmid, M.; Opravil, S.; Mechtler, K.; Ponting, C.P.; Allis, C.D.; et al. Regulation of chromatin structure by site-specific histone H3 methyltransferases. Nature 2000, 406, 593-599. [CrossRef] [PubMed]

103. Nakayama, J.; Rice, J.C.; Strahl, B.D.; Allis, C.D.; Grewal, S.I. Role of histone H3 lysine 9 methylation in epigenetic control of heterochromatin assembly. Science 2001, 292, 110-113. [CrossRef] [PubMed]

104. Tachibana, M.; Sugimoto, K.; Fukushima, T.; Shinkai, Y. Set domain-containing protein, G9a, is a novel lysine-preferring mammalian histone methyltransferase with hyperactivity and specific selectivity to lysines 9 and 27 of histone H3. J. Biol. Chem. 2001, 276, 25309-25317. [CrossRef]

105. Schultz, D.C.; Ayyanathan, K.; Negorev, D.; Maul, G.G.; Rauscher, F.J., 3rd. SETDB1: A novel KAP-1-associated histone $\mathrm{H} 3$, lysine 9-specific methyltransferase that contributes to HP1-mediated silencing of euchromatic genes by KRAB zinc-finger proteins. Genes Dev. 2002, 16, 919-932. [CrossRef]

106. Cao, R.; Wang, L.; Wang, H.; Xia, L.; Erdjument-Bromage, H.; Tempst, P.; Jones, R.S.; Zhang, Y. Role of histone H3 lysine 27 methylation in Polycomb-group silencing. Science 2002, 298, 1039-1043. [CrossRef]

107. McKittrick, E.; Gafken, P.R.; Ahmad, K.; Henikoff, S. Histone H3.3 is enriched in covalent modifications associated with active chromatin. Proc. Natl. Acad. Sci. USA 2004, 101, 1525-1530. [CrossRef]

108. Hake, S.B.; Garcia, B.A.; Duncan, E.M.; Kauer, M.; Dellaire, G.; Shabanowitz, J.; Bazett-Jones, D.P.; Allis, C.D.; Hunt, D.F. Expression patterns and post-translational modifications associated with mammalian histone $\mathrm{H} 3$ variants. J. Biol. Chem. 2006, 281, 559-568. [CrossRef]

109. Wang, H.; Huang, Z.Q.; Xia, L.; Feng, Q.; Erdjument-Bromage, H.; Strahl, B.D.; Briggs, S.D.; Allis, C.D.; Wong, J.; Tempst, P.; et al. Methylation of histone $\mathrm{H} 4$ at arginine 3 facilitating transcriptional activation by nuclear hormone receptor. Science 2001, 293, 853-857. [CrossRef]

110. Strahl, B.D.; Briggs, S.D.; Brame, C.J.; Caldwell, J.A.; Koh, S.S.; Ma, H.; Cook, R.G.; Shabanowitz, J.; Hunt, D.F.; Stallcup, M.R.; et al. Methylation of histone $\mathrm{H} 4$ at arginine 3 occurs in vivo and is mediated by the nuclear receptor coactivator PRMT1. Curr. Biol. 2001, 11, 996-1000. [CrossRef]

111. Nishioka, K.; Rice, J.C.; Sarma, K.; Erdjument-Bromage, H.; Werner, J.; Wang, Y.; Chuikov, S.; Valenzuela, P.; Tempst, P.; Steward, R.; et al. PR-Set7 is a nucleosome-specific methyltransferase that modifies lysine 20 of histone $\mathrm{H} 4$ and is associated with silent chromatin. Mol. Cell 2002, 9, 1201-1213. [CrossRef]

112. Schotta, G.; Lachner, M.; Sarma, K.; Ebert, A.; Sengupta, R.; Reuter, G.; Reinberg, D.; Jenuwein, T. A silencing pathway to induce H3-K9 and H4-K20 trimethylation at constitutive heterochromatin. Genes Dev. 2004, 18, 1251-1262. [CrossRef] [PubMed]

113. Fang, J.; Feng, Q.; Ketel, C.S.; Wang, H.; Cao, R.; Xia, L.; Erdjument-Bromage, H.; Tempst, P.; Simon, J.A.; Zhang, Y. Purification and functional characterization of SET8, a nucleosomal histone H4-lysine 20-specific methyltransferase. Curr. Biol. 2002, 12, 1086-1099. [CrossRef]

114. Kuo, M.H.; Brownell, J.E.; Sobel, R.E.; Ranalli, T.A.; Cook, R.G.; Edmondson, D.G.; Roth, S.Y.; Allis, C.D. Transcription-linked acetylation by Gen5p of histones H3 and H4 at specific lysines. Nature 1996, 383, $269-272$. [CrossRef] [PubMed]

115. Winkler, G.S.; Kristjuhan, A.; Erdjument-Bromage, H.; Tempst, P.; Svejstrup, J.Q. Elongator is a histone H3 and $\mathrm{H} 4$ acetyltransferase important for normal histone acetylation levels in vivo. Proc. Natl. Acad. Sci. USA 2002, 99, 3517-3522. [CrossRef] [PubMed]

116. Hilfiker, A.; Hilfiker-Kleiner, D.; Pannuti, A.; Lucchesi, J.C. mof, a putative acetyl transferase gene related to the Tip60 and MOZ human genes and to the SAS genes of yeast, is required for dosage compensation in Drosophila. EMBO J. 1997, 16, 2054-2060. [CrossRef]

117. Alaskhar Alhamwe, B.; Khalaila, R.; Wolf, J.; von Bulow, V.; Harb, H.; Alhamdan, F.; Hii, C.S.; Prescott, S.L.; Ferrante, A.; Renz, H.; et al. Histone modifications and their role in epigenetics of atopy and allergic diseases. Allergy Asthma Clin. Immunol. 2018, 14, 39. [CrossRef]

118. Schafer, A.; Baric, R.S. Epigenetic Landscape during Coronavirus Infection. Pathogens 2017, 6, 8. [CrossRef]

119. Zhang, Y.H.; Meng, J.L.; Gao, Y.; Zhang, J.Y.; Niu, S.L.; Yu, X.Z.; Li, Y.B.; Guan, Y.T.; Sun, B.X.; Zhao, Z.H. Changes in methylation of genomic DNA from chicken immune organs in response to H5N1 influenza virus infection. Genet. Mol. Res. 2016, 15. [CrossRef] 
120. Mukherjee, S.; Vipat, V.C.; Chakrabarti, A.K. Infection with influenza A viruses causes changes in promoter DNA methylation of inflammatory genes. Influenza Other Respir Viruses 2013, 7, 979-986. [CrossRef]

121. Tang, B.; Zhao, R.; Sun, Y.; Zhu, Y.; Zhong, J.; Zhao, G.; Zhu, N. Interleukin-6 expression was regulated by epigenetic mechanisms in response to influenza virus infection or dsRNA treatment. Mol. Immunol. 2011, 48, 1001-1008. [CrossRef]

122. Menachery, V.D.; Eisfeld, A.J.; Schafer, A.; Josset, L.; Sims, A.C.; Proll, S.; Fan, S.; Li, C.; Neumann, G.; Tilton, S.C.; et al. Pathogenic influenza viruses and coronaviruses utilize similar and contrasting approaches to control interferon-stimulated gene responses. mBio 2014, 5, e01174-01114. [CrossRef]

123. Marcos-Villar, L.; Diaz-Colunga, J.; Sandoval, J.; Zamarreno, N.; Landeras-Bueno, S.; Esteller, M.; Falcon, A.; Nieto, A. Epigenetic control of influenza virus: Role of H3K79 methylation in interferon-induced antiviral response. Sci. Rep. 2018, 8, 1230. [CrossRef] [PubMed]

124. Marcos-Villar, L.; Pazo, A.; Nieto, A. Influenza Virus and Chromatin: Role of the CHD1 Chromatin Remodeler in the Virus Life Cycle. J. Virol. 2016, 90, 3694-3707. [CrossRef] [PubMed]

125. Huarte, M.; Sanz-Ezquerro, J.J.; Roncal, F.; Ortin, J.; Nieto, A. PA subunit from influenza virus polymerase complex interacts with a cellular protein with homology to a family of transcriptional activators. J. Virol. 2001, 75, 8597-8604. [CrossRef] [PubMed]

126. Alfonso, R.; Lutz, T.; Rodriguez, A.; Chavez, J.P.; Rodriguez, P.; Gutierrez, S.; Nieto, A. CHD6 chromatin remodeler is a negative modulator of influenza virus replication that relocates to inactive chromatin upon infection. Cell Microbiol. 2011, 13, 1894-1906. [CrossRef] [PubMed]

127. Lavin, Y.; Winter, D.; Blecher-Gonen, R.; David, E.; Keren-Shaul, H.; Merad, M.; Jung, S.; Amit, I. Tissue-resident macrophage enhancer landscapes are shaped by the local microenvironment. Cell 2014, 159, 1312-1326. [CrossRef]

128. Hayward, S.L.; Scharer, C.D.; Cartwright, E.K.; Takamura, S.; Li, Z.T.; Boss, J.M.; Kohlmeier, J.E. Environmental cues regulate epigenetic reprogramming of airway-resident memory CD8(+) T cells. Nat. Immunol. 2020, 21, 309-320. [CrossRef]

129. Li, X.; Egervari, G.; Wang, Y.; Berger, S.L.; Lu, Z. Regulation of chromatin and gene expression by metabolic enzymes and metabolites. Nat. Rev. Mol. Cell Biol. 2018, 19, 563-578. [CrossRef]

130. O'Sullivan, D. The metabolic spectrum of memory T cells. Immunol. Cell Biol. 2019, 97, 636-646. [CrossRef]

131. Shi, L.; Tu, B.P. Acetyl-CoA and the regulation of metabolism: Mechanisms and consequences. Curr. Opin. Cell Biol. 2015, 33, 125-131. [CrossRef] [PubMed]

132. Qiu, J.; Villa, M.; Sanin, D.E.; Buck, M.D.; O'Sullivan, D.; Ching, R.; Matsushita, M.; Grzes, K.M.; Winkler, F.; Chang, C.H.; et al. Acetate Promotes T Cell Effector Function during Glucose Restriction. Cell Rep. 2019, 27, 2063-2074.e2065. [CrossRef] [PubMed]

133. Chandele, A.; Joshi, N.S.; Zhu, J.; Paul, W.E.; Leonard, W.J.; Kaech, S.M. Formation of IL-7Ralphahigh and IL-7Ralphalow CD8 T cells during infection is regulated by the opposing functions of GABPalpha and Gfi-1. J. Immunol. 2008, 180, 5309-5319. [CrossRef] [PubMed]

134. Navarro, M.N.; Goebel, J.; Feijoo-Carnero, C.; Morrice, N.; Cantrell, D.A. Phosphoproteomic analysis reveals an intrinsic pathway for the regulation of histone deacetylase 7 that controls the function of cytotoxic $\mathrm{T}$ lymphocytes. Nat. Immunol. 2011, 12, 352-361. [CrossRef]

135. Bannister, A.J.; Kouzarides, T. Regulation of chromatin by histone modifications. Cell Res. 2011, 21, 381-395. [CrossRef]

136. Tough, D.F.; Rioja, I.; Modis, L.K.; Prinjha, R.K. Epigenetic Regulation of T Cell Memory: Recalling Therapeutic Implications. Trends Immunol. 2020, 41, 29-45. [CrossRef]

137. Dogra, P.; Ghoneim, H.E.; Abdelsamed, H.A.; Youngblood, B. Generating long-lived CD8(+) T-cell memory: Insights from epigenetic programs. Eur. J. Immunol. 2016, 46, 1548-1562. [CrossRef] [PubMed]

138. Henning, A.N.; Roychoudhuri, R.; Restifo, N.P. Epigenetic control of CD8(+) T cell differentiation. Nat. Rev. Immunol. 2018, 18, 340-356. [CrossRef]

139. Belz, G.T.; Xie, W.; Altman, J.D.; Doherty, P.C. A previously unrecognized H-2D(b)-restricted peptide prominent in the primary influenza A virus-specific CD8(+) T-cell response is much less apparent following secondary challenge. J. Virol. 2000, 74, 3486-3493. [CrossRef]

140. He, B.; Xing, S.; Chen, C.; Gao, P.; Teng, L.; Shan, Q.; Gullicksrud, J.A.; Martin, M.D.; Yu, S.; Harty, J.T.; et al. CD8(+) T Cells Utilize Highly Dynamic Enhancer Repertoires and Regulatory Circuitry in Response to Infections. Immunity 2016, 45, 1341-1354. [CrossRef] 
141. Shin, H.M.; Kapoor, V.; Guan, T.; Kaech, S.M.; Welsh, R.M.; Berg, L.J. Epigenetic modifications induced by Blimp-1 Regulate CD8(+) T cell memory progression during acute virus infection. Immunity 2013, 39, 661-675. [CrossRef] [PubMed]

142. Zediak, V.P.; Johnnidis, J.B.; Wherry, E.J.; Berger, S.L. Cutting edge: Persistently open chromatin at effector gene loci in resting memory CD8+ T cells independent of transcriptional status. J. Immunol. 2011, 186, 2705-2709. [CrossRef] [PubMed]

143. Araki, Y.; Fann, M.; Wersto, R.; Weng, N.P. Histone acetylation facilitates rapid and robust memory CD8 $\mathrm{T}$ cell response through differential expression of effector molecules (eomesodermin and its targets: Perforin and granzyme B). J. Immunol. 2008, 180, 8102-8108. [CrossRef] [PubMed]

144. Turner, B.M. Cellular memory and the histone code. Cell 2002, 111, 285-291. [CrossRef]

145. Su, X.; Ren, C.; Freitas, M.A. Mass spectrometry-based strategies for characterization of histones and their post-translational modifications. Expert Rev. Proteom. 2007, 4, 211-225. [CrossRef] [PubMed]

146. Sidoli, S.; Vandamme, J.; Salcini, A.E.; Jensen, O.N. Dynamic changes of histone H3 marks during Caenorhabditis elegans lifecycle revealed by middle-down proteomics. Proteomics 2016, 16, 459-464. [CrossRef]

147. Schwammle, V.; Sidoli, S.; Ruminowicz, C.; Wu, X.; Lee, C.F.; Helin, K.; Jensen, O.N. Systems Level Analysis of Histone H3 Post-translational Modifications (PTMs) Reveals Features of PTM Crosstalk in Chromatin Regulation. Mol. Cell. Proteom. MCP 2016, 15, 2715-2729. [CrossRef]

148. Sidoli, S.; Lopes, M.; Lund, P.J.; Goldman, N.; Fasolino, M.; Coradin, M.; Kulej, K.; Bhanu, N.V.; Vahedi, G.; Garcia, B.A. A mass spectrometry-based assay using metabolic labeling to rapidly monitor chromatin accessibility of modified histone proteins. Sci. Rep. 2019, 9, 13613. [CrossRef]

149. Sidoli, S.; Lu, C.; Coradin, M.; Wang, X.; Karch, K.R.; Ruminowicz, C.; Garcia, B.A. Metabolic labeling in middle-down proteomics allows for investigation of the dynamics of the histone code. Epigenetics Chromatin 2017, 10, 34. [CrossRef]

150. Britton, L.-M.P.; Gonzales-Cope, M.; Zee, B.M.; Garcia, B.A. Breaking the histone code with quantitative mass spectrometry. Expert Rev. Proteom. 2011, 8, 631-643. [CrossRef]

Publisher's Note: MDPI stays neutral with regard to jurisdictional claims in published maps and institutional affiliations.

(C) 2020 by the authors. Licensee MDPI, Basel, Switzerland. This article is an open access article distributed under the terms and conditions of the Creative Commons Attribution (CC BY) license (http://creativecommons.org/licenses/by/4.0/). 